\title{
Position Paper on Nasal Obstruction: Evaluation and Treatment
}

\author{
Valero $A^{1}$, Navarro $A M^{2}$, del Cuvillo $A^{3}$, Alobid I ${ }^{4}$, Benito $\mathrm{JR}^{5}$, Colás $\mathrm{C}^{6}$, de los Santos $\mathrm{G}^{7}$, Fernández \\ Liesa $R^{8}$, García-Lliberós $A^{9}$, González-Pérez $R^{10}$, Izquierdo-Domínguez $A^{11}$, Jurado-Ramos $A^{12}$,

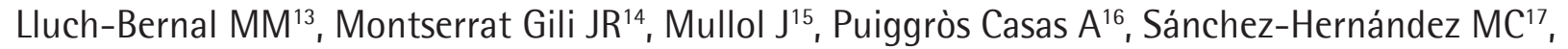 \\ Vega $\mathrm{F}^{18}$, Villacampa $\mathrm{JM}^{19}$, Armengot-Carceller $\mathrm{M}^{20, *}$, Dordal $\mathrm{MT}^{21,22,{ }^{*}}$ \\ (SEAIC Rhinoconjunctivitis Committee \&t SEORL Rhinology, Allergy, and Skull Base Committee)
}

\author{
*Both authors contributed equally. \\ 'Servicio de Neumología y Alergia, Hospital Clínic; Immunoal-lèrgia Respiratòria Clínica i Experimental, Institut d'Investigacions Biomèdiques \\ August Pi i Sunyer (IDIBAPS); CIBERES Barcelona, Spain \\ ${ }^{2}$ UGC Alergología, Hospital El Tomillar AGS Sur Sevilla, Spain \\ ${ }^{3}$ Unidad de Rinología y Asma, UGC Otorrinolaringología, Hospital de Jerez, Cádiz, Spain \\ ${ }^{4} U$ nitat de Rinologia i Clínica de l'Olfacte, Hospital Clínic, Barcelona, Spain \\ ${ }^{5}$ Unidad de Rinología, UGC ORL, Hospital Universitario Puerto Real, Cádiz, Spain \\ ${ }^{6}$ Hospital Clínico-Instituto de Investigación Sanitaria Aragón, Zaragoza, Spain \\ `Unidad de Rinología y Base del cráneo anterior, Servicio de Otorrinolaringología, Hospital Universitario Ramón y Cajal, Madrid, Spain \\ ${ }^{8}$ Hospital Universitario Miguel Servet, Zaragoza, Spain \\ ${ }^{9}$ Servicio de Otorrinolaringología, Sección de Rinología, Hospital de Manises, Valencia, Spain \\ ${ }^{10}$ Unidad de Alergia, Hospital del Tórax, Complejo Hospital Universitario Nuestra S. de Candelaria, Santa Cruz de Tenerife, Spain \\ ${ }^{11}$ Consorci Sanitari de Terrassa, Barcelona, Spain \\ ${ }^{12}$ Hospital San Juan de Dios, Córdoba, Spain \\ ${ }^{13}$ Servicio de Alergia, Hospital La Paz, Madrid, Spain \\ ${ }^{14}$ Sección de Rinología del Servicio de ORL, Hospital Santa Creu i Sant Pau, Barcelona, Spain \\ ${ }^{15}$ Unitat de Rinologia i Clínica de I'Olfacte, Servei d' ORL, Hospital Clínic i Universitari; Immunoal-lèrgia Respiratòria Clínica i Experimental, \\ Institut d'Investigacions Biomèdiques August Pi i Sunyer (IDIBAPS); CIBERES, GA2LEN, EUFOREA, Barcelona, Spain \\ ${ }^{16}$ Hospital Quirón, Barcelona, Spain \\ ${ }^{17}$ UCG Alergología, Hospital Universitario Virgen Macarena, Sevilla, Spain \\ ${ }^{18}$ Servicio de Alergia, Hospital Universitario de la Princesa, Instituto de Investigación Sanitaria - Hospital Universitario de La Princesa (IP), \\ Madrid, Spain \\ ${ }^{19}$ Servicio de Otorrinolaringología y Patología Cérvico-facial, Hospital Universitario Fundación Jiménez Díaz IDC, Madrid, Spain \\ ${ }^{20}$ Servicio de Otorrinolaringología, Hospital Universitari i Politècnic la Fe, Universitat de València, Valencia, Spain \\ ${ }^{21}$ Unitat d'Al-lèrgia, Badalona Serveis Assistencials, Badalona, Spain \\ ${ }^{22}$ Servei d'Al-lèrgia, Sant Pere Claver Fundació Sanitària, Barcelona, Spain
}

J Investig Allergol Clin Immunol 2018; Vol. 28(2): 67-90

doi: 10.18176/jiaci.0232

\section{Abstract}

Nasal obstruction (NO) is defined as the subjective perception of discomfort or difficulty in the passage of air through the nostrils. It is a common reason for consultation in primary and specialized care and may affect up to $30 \%-40 \%$ of the population. It affects quality of life (especially sleep) and lowers work efficiency.

The aim of this document is to agree on how to treat NO, establish a methodology for evaluating and diagnosing it, and define an individualized approach to its treatment.

NO can be unilateral or bilateral, intermittent or persistent and may be caused by local or systemic factors, which may be anatomical, inflammatory, neurological, hormonal, functional, environmental, or pharmacological in origin. Directed study of the medical history and physical examination are key for diagnosing the specific cause. NO may be evaluated using subjective assessment tools (visual analog scale, symptom score, standardized questionnaires) or by objective estimation (active anterior rhinomanometry, acoustic rhinometry, peak nasal inspiratory flow). Although there is little correlation between the results, they may be considered complementary and not exclusive. Assessing the impact on quality of life through questionnaires standardized according to the underlying disease is also advisable. NO is treated according to its cause. Treatment is fundamentally pharmacological (topical and/or systemic) when the etiology is inflammatory or functional. Surgery may be necessary when medical treatment fails to complement or improve medical treatment or when other therapeutic approaches are not possible. Combinations of surgical techniques and medical treatment may be necessary.

Key words: Nasal obstruction/nasal blockage/nasal respiratory insufficiency. Objective and subjective evaluation. Acoustic rhinometry. Rhinomanometry. Medical and surgical treatment. 


\section{Resumen}

La obstrucción nasal (ON) se define como la percepción subjetiva de disconfort o dificultad en el paso del aire a través de las fosas nasales. Es un motivo de consulta frecuente en atención primaria y especializada, que puede afectar hasta un 30-40\% de la población. Repercute en la calidad de vida (especialmente con alteración del sueño) y disminuye la eficiencia laboral.

El objetivo de este documento es consensuar el manejo de la ON, estableciendo una metodología para su evaluación y diagnóstico y un abordaje individualizado para el tratamiento.

La ON puede ser uni o bilateral, intermitente o persistente y debida a factores locales o sistémicos, ya sean anatómicos, inflamatorios, neurológicos, hormonales, funcionales, ambientales o medicamentosos. La anamnesis dirigida y la exploración física son claves para el diagnóstico diferencial. La evaluación de la ON puede realizarse con herramientas de valoración subjetiva (escala visual analógica, puntuación de síntomas, cuestionarios estandarizados) o por estimación objetiva (rinomanometría anterior activa, rinometría acústica, flujo máximo nasal inspiratorio). Aunque existe poca correlación entre ellas, sus resultados pueden considerarse complementarios y no excluyentes. También es aconsejable valorar el impacto en la calidad de vida mediante cuestionarios estandarizados.

El tratamiento de la ON se establece en función de la causa. Es fundamentalmente farmacológico (tópico y/o sistémico) cuando la etiología es inflamatoria o funcional. El tratamiento quirúrgico estará indicado tras el fracaso del tratamiento médico, para complementarlo 0 mejorarlo. Puede ser necesaria la combinación de varias técnicas quirúrgicas y/o la asociación de un tratamiento médico pre/post cirugía.

Palabras clave: Obstrucción nasal. Evaluación objetiva y subjetiva. Rinometría acústica. Rinomanometría. Tratamiento médico y quirúrgico.

\section{Background and Objectives}

Nasal obstruction (NO) is defined as the subjective perception of discomfort or difficulty in the passage of air through the nostrils. It is thought that this sensation is physiologically or pathologically generated in the trigeminal sensory receptors of the nasal mucosa. The terms obstruction and nasal congestion may be used as synonyms, although obstruction usually refers to the subjective sensation of irreversible blockage.

NO affects almost half of the population [1] and is one of the most common reasons for consultation in primary care, otorhinolaryngology, and allergology [2,3].

The condition can be caused by anatomical, inflammatory, neurological, hormonal, functional, environmental, and pharmacological factors. Furthermore, its etiology may be multifactorial, thus making diagnosis and treatment more complex.

$\mathrm{NO}$ is an annoying symptom that greatly affects quality of life (QOL), predisposes to and exacerbates lower airway diseases, alters night rest, decreases work efficiency, and aggravates sleep apnea [4,5].

Diagnosis of its specific cause is essential for selecting appropriate therapy. The enormous social and health care expenditure that it generates results from factors such as incorrect diagnoses and/or unsuitable treatment [6].

The objectives of this document are to reach agreement on management of $\mathrm{NO}$ and to establish a methodology for its evaluation, diagnosis, and treatment with the aim of enabling patients to breathe better through the nose.

\section{Methods}

This position paper on NO was drawn up using an iterative review methodology, whereby the sections of the document are drafted by groups of 2 or 3 people after which all the authors review, correct, and contribute to the whole manuscript.
To draw up the content of each section, the authors systematically reviewed the available bibliography using the OVID Medline tools and the Embase and Cochrane Review databases to select the best scientific evidence available on which to base the assertions and recommendations formulated in this document.

The quality of the scientific evidence and its risk of error were critically evaluated following the criteria of the Centre for Evidence-Based Medicine, Oxford, UK [7].

\section{Epidemiology and Pathophysiology}

NO is a symptom that is frequently reported by patients in primary care and otorhinolaryngology and allergy consultations $[2,3,8]$. Although there are no precise data, it is estimated that the condition may affect at least $30 \%-40 \%$ of the general population [1].

Indirect epidemiological data usually proceed from 2 sources: on the one hand, the number and frequency of functional nasal surgeries performed, which in some European countries ranges between 40 and 75 septoplasties per 100000 inhabitants [2], and on the other, the presence of NO symptoms in sinonasal disease. In allergic rhinitis (AR), whose prevalence ranges from $10 \%$ to $40 \%$ [9], NO affects $80 \%$ of patients and is the main symptom in $50 \%-75 \%$ of cases [10]. Similar data are found in patients with nonallergic rhinopathy [10]. The prevalence of rhinosinusitis is estimated at $10 \%$ of the population [9], with $\mathrm{NO}$ at between $65 \%$ and $70 \%$ [9].

Physiologically, the nasal passages are both a sensory and respiratory organ. The anatomy of the nasal cavity is divided along the sagittal plane by the septum into 2 nostrils, of which the lateral wall includes the turbinates, which tend to adapt to nasal volume while increasing the mucosal surface. The limen nasi, or internal nasal valve, connects the nasal aperture with the nasal fossa and represents the narrowest area of the entire cavity. The nasal valve and turbinates are the main areas of resistance to airflow in the nasal passages, constituting $50 \%$ of 
Table 1. Causes Of Nasal Obstruction (Unilateral and Bilateral) According to Age Group

\begin{tabular}{lll}
\hline & & Cause of Nasal Obstruction \\
\hline Age Group & Unilateral & Bilateral \\
\hline Children & Malformations & Malformations \\
& Foreign bodies & Inflammatory or infectious rhinitis \\
& Benign or malignant tumors & Chronic rhinosinusitis with or without polyps \\
& Unilateral chronic rhinosinusitis & Adenoid hypertrophy \\
& Antrochoanal polyp & Turbinate hypertrophy \\
\hline Teenagers & Meptal deviation & \\
& Angiofibroma and other benign or malignant tumors & Rhinitis of different causes (eg, allergic, hormonal) \\
& Unilateral chronic rhinosinusitis & Chronic rhinosinusitis with or without polyps \\
& Antrochoanal polyp & Malformations \\
& Septal deviation & Adenoid hypertrophy \\
& Concha bullosa & Benign or malignant tumors \\
& Septal deviation & Turbinate hypertrophy \\
\hline Adults & Unilateral chronic rhinosinusitis & Rhinitis of different causes (eg, allergic, pregnancy, medication) \\
& Antrochoanal polyp & Chronic rhinosinusitis with or without nasal polyps \\
& Benign or malignant tumors & Benign or malignant tumors \\
& Concha bullosa & Systemic diseases \\
& & Turbinate hypertrophy \\
& & Valvular insufficiency \\
& & Empty nose syndrome
\end{tabular}

total resistance in the respiratory tree [11]. The vascularization of the nasal mucosa consists of at least 4 types of vessels with marked physiological relevance in nasal resistance [12]. The cavernous sinusoids are interposed between capillaries and venules, especially at the level of the turbinates. The endothelial layer is continuous, with a network of collagen and elastic fibers surrounded by smooth muscle cells whose activity enables the sinusoids to change volume rapidly depending on their state of blood congestion/decongestion [13]. The fossae and paranasal sinuses have complex sensory and autonomic innervation, with the control of secretions and vasodilatation being considered parasympathetic $[14,15]$. Local anesthesia or ablation of the sympathetic fibers inhibits the unilateral periodic engorgement of the mucosa responsible for obstruction, which is characteristic of the nasal cycle [16]. The neural mechanisms that control vascular flow and nasal congestion are unknown [17].

NO is produced by all those causes that hinder airflow through the nostrils and may be unilateral or bilateral (Table 1). It is caused either by inflammation of the nasal mucosa or by an anatomical abnormality that hinders flow, both of which result in a narrowing of the nasal cavity and a subjective sensation of blockage or nasal congestion [18]. Inflammation of the sinonasal mucosa is the central pathophysiological mechanism of most of the factors that contribute to NO, such as venous engorgement, increased nasal secretions, and tissue edema. These factors are seen mainly in disorders of the upper respiratory tract such as AR, nonallergic rhinitis (NAR), chronic rhinosinusitis (CRS) with or without nasal polyposis (NP) [19], systemic vasculitis, and even as an adverse effect of some drugs. Mechanical and/or structural anatomical abnormalities of the nasal cavities are also an important cause of NO. These include septal deviation, nasal valve insufficiency, turbinate or adenoid hypertrophy, choanal atresia, middle turbinate pneumatization, neoplasms, and the presence of foreign bodies. In some patients, there is increasing evidence of the involvement of a neurogenic signaling mechanism that causes the sensation of $\mathrm{NO}$ in the absence of real obstruction of the nasal passages [20].

\section{Medical History and Clinical Examination}

Medical history and physical examination are the basis for drawing up a proper diagnostic-therapeutic plan for NO [21].

\section{Medical History}

NO is the major symptom of a broad spectrum of diseases [22], and, before a suitable, specific diagnosis can be made, it must be characterized by taking a focused medical history including the following:

- Onset: acute or chronic, and progress.

- Laterality: unilateral (suggests structural causes or foreign body in children; if NO progresses, sinonasal tumor must be suspected) or bilateral (suggests inflammation of mucous membranes).

- Duration of symptoms: intermittent or persistent. Assess alternation, annual seasonality, and diurnal variability (work, home, physical activity) and nocturnal variability (worsens in decubitus or sleeping on one particular side), which suggest an inflammatory or functional cause.

- Disease severity: severity of symptoms using a visual analog scale (VAS) [23] or questionnaires that evaluate NO, such as the Nasal Obstruction Symptom Evaluation (NOSE) [23] or the Congestion Quantifier Seven-Item 
Test (CQ7) [24], which has been validated for the Spanish population.

- Effect on QOL: specific questionnaires for sinonasal disease.

- Triggers: allergic, physical or chemical stimuli, infections, injury, surgery, pregnancy, environmentalprofessional, changes in usual medication (any drug or biological process [eg, pregnancy or hypothyroidism] that directly or indirectly leads to a predominance of the parasympathetic system will cause NO).

- Nasal symptoms: Pruritus, sneezing, and rhinorrhea are associated with inflammatory or infectious conditions; pain, hyposmia/anosmia, and thick rhinorrhea are associated with sinonasal disease; anatomical deformity and epistaxis suggest an aggressive etiology.

- Comorbidities: In patients with rhinitis, the presence of asthma [25], conjunctivitis, CRS, pharyngeal symptoms, visual disturbances, nervous dysfunctions, or systemic symptoms suggestive of vasculitis should be assessed.

- Personal history: Data should be gathered on history of atopy, exposure (allergenic, occupational, or irritant), trauma, nasal surgery, recurrent sinusitis, rhinitis/ asthma caused by nonsteroidal anti-inflammatory drugs, obstructive sleep apnea, cystic fibrosis, hypothyroidism, pregnancy, chronic infectious diseases (syphilis, leprosy, tuberculosis), systemic vasculitis (Wegener disease and Churg-Strauss syndrome), and malignant vasculitis [26].

- Drugs and substance abuse: Record the use of intranasal decongestants, regular medication that can influence obstruction (antithyroid drugs, antipsychotics, antihypertensives, oral contraceptives, antidepressants), cocaine, and tobacco [27].

\section{Examination}

When compiling the medical history, we must note any indirect signs such as constant oral breathing, rhinolalia (open or closed), and allergic salute.
- Inspection. Assess the appearance of the nasal skin, protrusions, asymmetries, or lateralization of the cartilaginous and/or bony nasal pyramid. Record dynamic or static nostril collapse in inspiration and columellar anomalies such as asymmetry or dislocation of the quadrangular cartilage over the columella.

- Palpation. Palpate sinus points (supraorbital, infraorbital, Ewing, or ethmoidal), to assess whether it triggers pain or crepitus. In the bone and cartilaginous pyramid, note asymmetries, crepitation, lack of support, or subsidence. Assess alignment and consistency in the anterior septum and columella.

- Anterior rhinoscopy: The rhinoscope (or otoscope in children) enables us to assess the anterior third of the nose (Cottle areas 1 and 2, and part of the third) [28], which includes the most caudal region of the septum, the nasal valve, and the head of the inferior turbinates. Sometimes the head of the middle turbinate and the cavum may be observed. The nasal mucosa should be evaluated for pink and moist appearance (normal), signs of atrophy/dryness (dry rhinitis), scabs (vasculitis or chronic atrophic rhinitis), congestive mucosa (rhinitis and/or rhinosinusitis), and pale mucosa (allergic or drug-induced rhinitis). Investigate the presence of deviations, synechiae, perforations, and rhinorrhea and their characteristics. In the case of turbinate hypertrophy it is very useful to observe permeability and appearance after administering a topical vasoconstrictor. It is very important to detect occupation of the nasal passages either bilaterally (polyps) or unilaterally (tumors).

- Posterior rhinoscopy. This approach has fallen into disuse with the generalization of endoscopy.

- Nasal endoscopy (rigid or flexible): Provides a detailed examination of the nasal passages [21]. The optic device is introduced along the inferior meatus to visualize the cavum and then progressively retracted to assess the

Table 2. Cottle Areas and Their Limits (Modified From Zambetti et al [28])

\begin{tabular}{|c|c|c|c|c|}
\hline \multicolumn{5}{|c|}{ Limits of the cottle areas } \\
\hline & Superior & Inferior & Medial & Lateral \\
\hline $\begin{array}{l}\text { Area 1: Vestibule } \\
(0.5 \mathrm{~cm})\end{array}$ & $\begin{array}{l}\text { The alar cupula, the rear } \\
\text { junction of the triangular } \\
\text { cartilage and piriform orifice }\end{array}$ & $\begin{array}{l}\text { Recess limited by the cupula } \\
\text { of the alar cartilage }\end{array}$ & Nasal septum & $\begin{array}{l}\text { Alar cartilage and } \\
\text { the medial wall of } \\
\text { the nasal ala }\end{array}$ \\
\hline $\begin{array}{l}\text { Area 2: Valve } \\
(1.5 \mathrm{~cm})\end{array}$ & $\begin{array}{l}\text { Lower extremity of } \\
\text { the triangular cartilage }\end{array}$ & $\begin{array}{l}\text { Lower margin of the piriform } \\
\text { orifice } \\
\text { Anterior and premaxillary } \\
\text { nasal bone }\end{array}$ & Nasal septum & $\begin{array}{l}\text { Fibrofatty tissue } \\
\text { extending to the } \\
\text { piriform aperture }\end{array}$ \\
\hline $\begin{array}{l}\text { Area 3: Attic } \\
(2.5 \mathrm{~cm})\end{array}$ & Naso-frontal suture & $\begin{array}{l}\text { Upper lateral cartilage partially } \\
\text { covered by nasal bones (area K) }\end{array}$ & $\begin{array}{l}\text { Nasal septum and } \\
\text { contralateral nasal } \\
\text { bone }\end{array}$ & $\begin{array}{l}\text { Naso-frontal apophysis } \\
\text { of the maxilla }\end{array}$ \\
\hline $\begin{array}{l}\text { Area 4: Anterior } \\
\text { turbinate }(3.5 \mathrm{~cm})\end{array}$ & \multicolumn{4}{|c|}{$\begin{array}{c}\text { Anterior portion of the anterior nasal wall, including the turbinate } \\
\text { Medially, septal cartilage }\end{array}$} \\
\hline $\begin{array}{l}\text { Area 5: Posterior } \\
\text { or choanal turbinate } \\
(6 \mathrm{~cm})\end{array}$ & \multicolumn{4}{|c|}{$\begin{array}{l}\text { Posterior portion of the turbinates towards the choana } \\
\text { Medially, the corresponding portion of the perpendicular lamina of the ethmoid and the vomer }\end{array}$} \\
\hline
\end{tabular}


superior and middle turbinates and meatus. The presence, size, and laterality of septal deviations should be noted, as should any polypoid tumor masses and the presence of rhinorrhea in the 5 Cottle areas (Table 2 [28]).

- Functional maneuvers for exploring the nasal valve: explore collapse in forced inspiration [29]. The best known is the Cottle maneuver, which allows the angle of the valve to be increased [30].

- Examination of the remaining area (ear, nose, throat). Perform otoscopy and oropharyngoscopy. Laryngeal and pulmonary exploration depend on the patient's medical history. Given the high prevalence of comorbidity, it is very important to study the lower respiratory tract.

\section{Subjective Evaluation of NO}

NO can be evaluated subjectively by the physician using a Likert-type scale and by the patient using patient-reported outcomes based on a VAS or questionnaires that assess the effect of NO (NOSE, CQ7).

The VAS has been used to subjectively assess all nasal symptoms, including NO. A horizontal $10-\mathrm{cm}$ line is scored by marking it with a vertical line at the place where the patient considers that it best indicates the intensity of the symptom, from 0 to 10 . The left end ( 0 ) indicates the absence of NO and the right end (10) the maximum severity of NO (Figure 1).

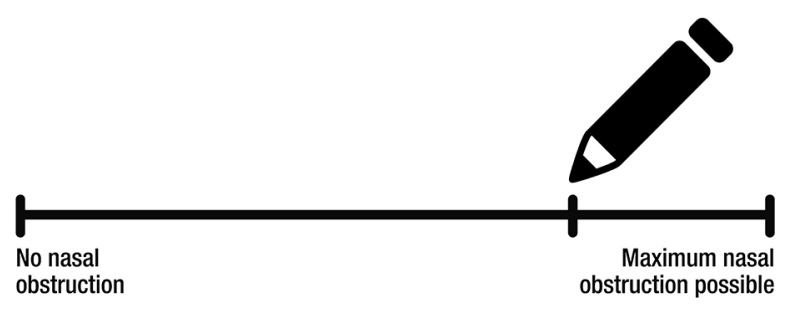

Figure 1. Visual analog scale for nasal obstruction.

The VAS is a well-studied tool for assessing the severity of NO and has been validated with reference to other subjective measures such as symptom score [31] and to objective measures such as rhinomanometry (RMN), acoustic rhinometry (AcR), and peak nasal inspiratory flow (PNIF) in adults [32,33] and nasal endoscopy in children [34]. It has been estimated that, in asymptomatic individuals, the mean VAS value used to assess NO ranges from 2.1 (2.2) to 4.6 (2.6) in the general population [23].

With the nasal symptom score, the intensity of symptoms is evaluated using a Likert-type scale, for example, from 0 to 3 , where $0=$ no symptoms, $1=$ mild symptoms, $2=$ moderate symptoms, and $3=$ severe symptoms. The Likert scale score on NO has been validated by comparing it with the VAS and AcR [31].

\section{Questionnaires to Assess the Impact of NO}

- NOSE. This questionnaire was designed to measure how NO affects QOL. It was initially designed for patients with septal deviation and contains 5 items rated using a 5-point Likert scale ranging from 0 (not a problem) to 4 (a serious problem), with the result expressed over a maximum of 100 by multiplying the sum of the answers obtained by 5 . The questionnaire has been translated into Spanish and validated, its psychometric properties are sufficient, and it is closely correlated with the VAS [35]. It has been estimated that the NOSE questionnaire yields a mean value of 15 (17) in the asymptomatic individual and 42 (27) in the general population [23].

- CQ7. This tool was designed to identify patients with nasal congestion and displays good psychometric characteristics and the ability to discriminate between different levels of severity of AR symptoms [24]. It consists of 7 questions rated on a scale of 0 (never) to 4 (always), with a score range of 0 to 28 . In the initial validation study, it was estimated that a score above 7 is the one that best identifies patients who require treatment. It has been translated into Spanish and validated. It discriminates well between degrees of severity of nasal congestion and is suitable for detecting, measuring, and monitoring NO [36].

- DyNaChron. This self-completed questionnaire aims to evaluate the functional symptoms originating in the nose and paranasal sinuses, along with their physical and psychosocial consequences. It is specific for chronic nasal dysfunction. However, as NO is the most annoying and frequent symptom in nasal dysfunction, it should be mentioned in this section. It comprises 78 items organized into 6 areas and is designed primarily for use in a research environment. It has been validated, and the need for a shorter adaptation for use in clinical practice has been suggested [37].

\section{Objective Evaluation}

The ideal test to measure NO would be the one that would enable us to quantify - in an objective and reproducible way - the pathogenic mechanism by which this subjective sensation is triggered. At present, resistance, flow, volume, and nasal geometry are measured, although we are far from having an ideal test.

Before the test, the patient must be advised to avoid local or systemic drugs that might modify the nasal mucosa. The patient is placed at rest, sitting comfortably for 30 minutes, before the examination begins. The examination room should be kept at a constant temperature $\left(18^{\circ} \mathrm{C}-22^{\circ} \mathrm{C}\right)$ and relative humidity $(50 \%-60 \%)$ and remain free of ambient noise, which should be less than $60 \mathrm{~dB}$ to $50 \mathrm{~dB}$ during AcR [38-41].

RMN. This technique enables simultaneous measurement of pressure debit and variations of the airflow in the nasal passages during the breathing cycle. It may be anterior (when the measurement systems are placed at the level of the nasal nostril) or posterior (requires the placement of an intra-oral device to register choanal pressure). Both modalities can be active (the subject breathes actively or spontaneously) or passive (the subject is in apnea and a predetermined airflow is propelled through the 
nostril) [38,40-42]. In its assessment of nasal patency, the International Standardisation Committee advises active anterior RMN (AARMN) using a face mask and a computerized record of pressure, flow, and resistance as the recommended test in daily clinical practice $[39,41]$. Active
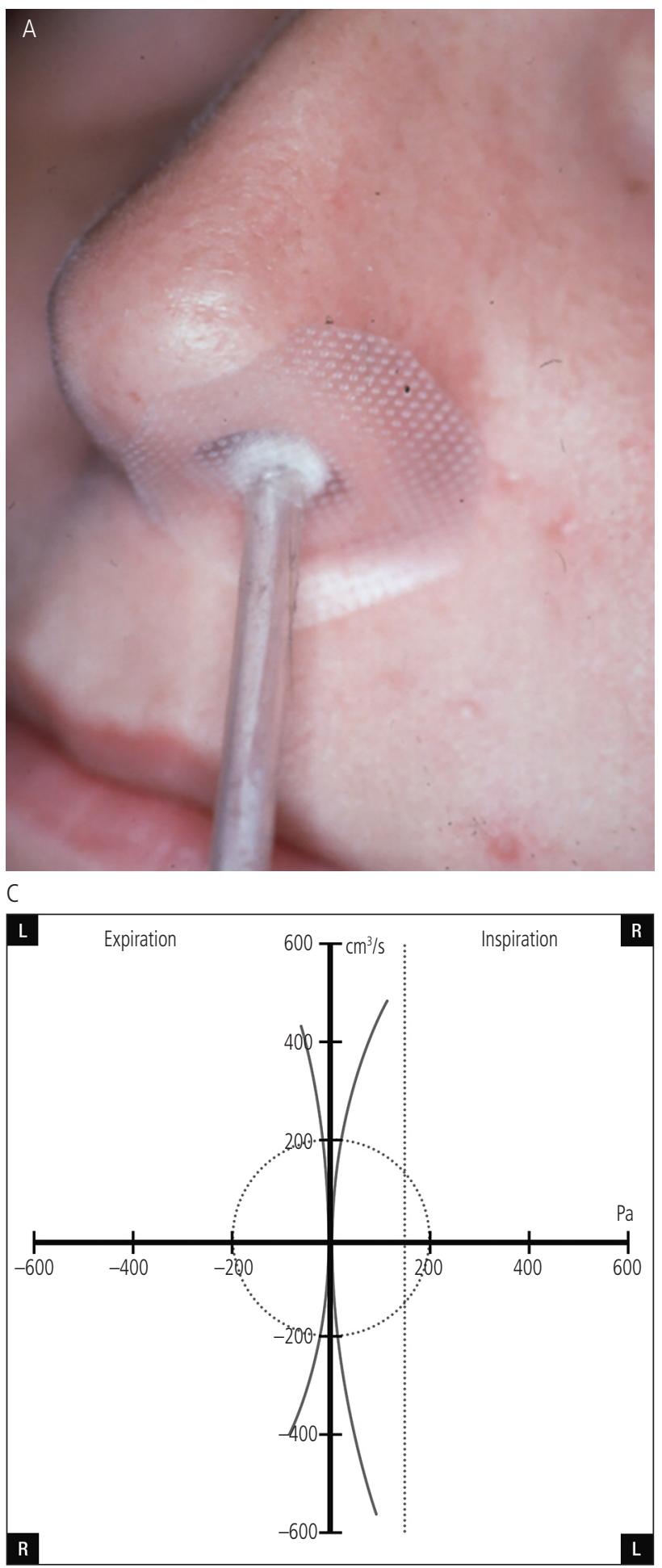

posterior RMN is advised specifically in septal perforation and occlusive septal deviations, given that a measurement for each nostril cannot be obtained separately. About $10 \%$ of measurements are false owing to movement of the tongue, salivation, or swallowing $[41,42]$.

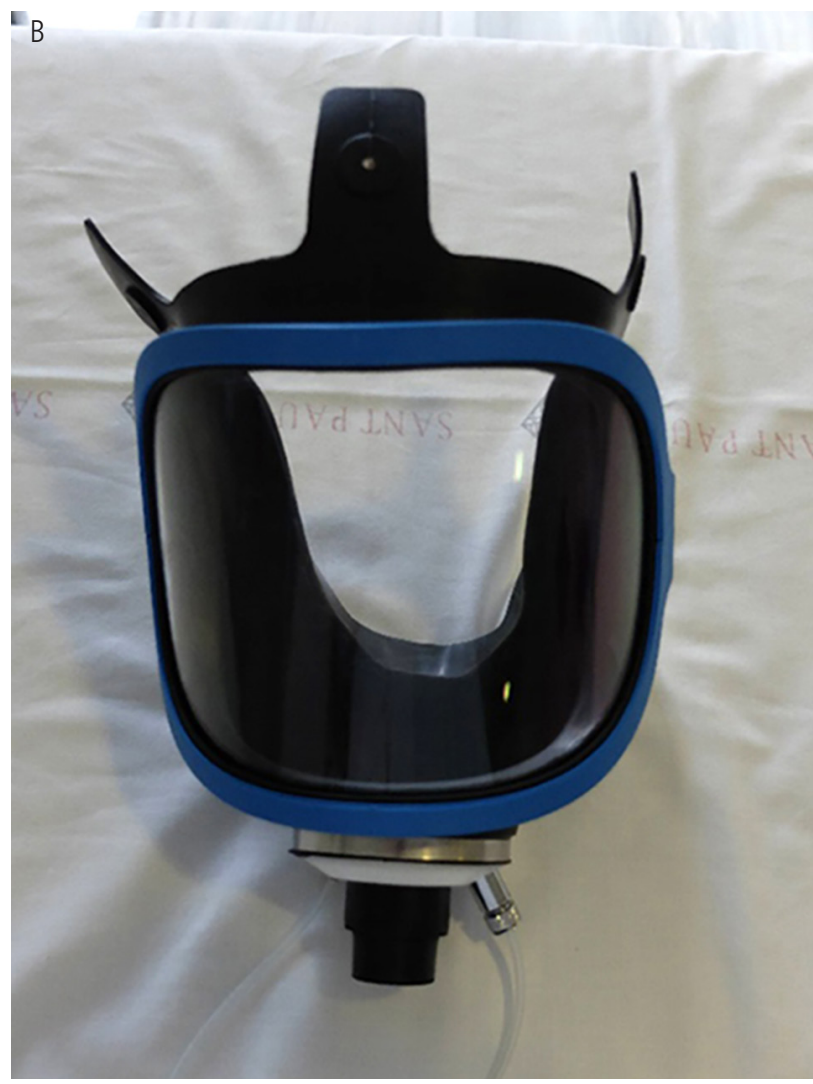

D

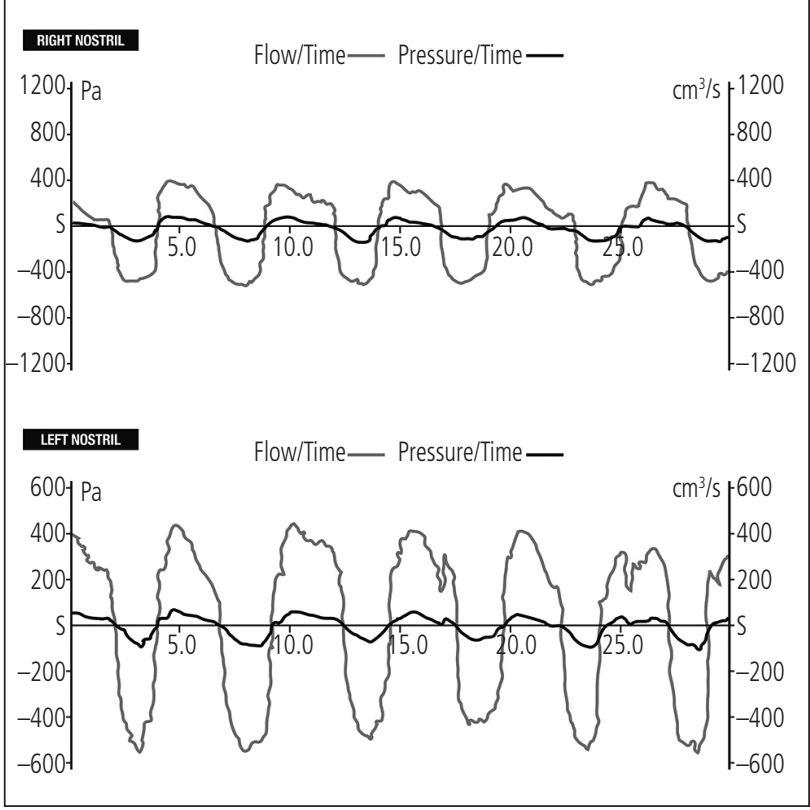

Figure 2. Active anterior rhinomanometry. A, Adhesive tape with cannula for measuring pressure. B, Face mask. C, XY recording axis (full consensus). D, Sinusoidal oscillograph (no general consensus). The flow and pressure values are recorded according to the time factor. 
In AARMN, the noninvestigated side is sealed using adhesive tape to measure pressure changes without distorting the nasal vestibule, while the airflow is measured in the unoccluded fossa (Figure 2). The test is performed under baseline conditions and after vasoconstriction. The comparison with baseline results allows us to assess whether nasal respiratory failure is more likely to be functional than structural [38-40]. Finally, a third test can be performed after dilatation of the valve area, although the precise valve dilatation technique has never been properly agreed. In this test, significant changes in pressure and flow would be interpreted as the result of mechanical obstruction in the valve area [38].

The reference values obtained using AARMN have not been fully agreed. Some degree of variability is accepted according to the equipment used, age, weight, and the racial-ethnic characteristics of the population groups under study $[41,43]$. Table 3 shows the normal range of values in our geographical area for a population of leptorrhines, with no symptoms of NO or significant anatomical abnormalities [38]. In the same population, the normal values of unilateral nasal resistance at $100 / 150 \mathrm{~Pa}$ are $<0.36 /<0.45 \mathrm{~Pa} / \mathrm{cm}^{3} / \mathrm{s}$, and the normal values of bilateral nasal resistance at $100 / 150 \mathrm{~Pa}$ are $<0.18 / 0.22 \mathrm{~Pa} / \mathrm{cm}^{3} / \mathrm{s}$, respectively [38].

Using AARMN, the nasal response can also be quantified after exposure to irritants or allergens [44]. If nasal resistance increases by $100 \%$ or more, the result is considered positive $[42,44]$.

A new 4-phase calculation algorithm was recently proposed for AARMN and includes all phases of the nasal respiratory cycle, namely, acceleration and deceleration, both in inspiratory and expiratory phases. In addition to obtaining quantitative values, this is intended to introduce the measurement of parameters that would correlate better with the subjective sensation of nasal breathing $[42,45]$.

AcR. This objective method for exploring the geometry of the nasal cavity enables us to analyze the acoustic reflection of a sound wave that travels along the nasal cavity and to measure areas and volumes at different points in the nasal fossa (Figure 3 A, B, and D) [46-48]. It is very difficult to define a normal nasal fossa. Countless variables must be taken into account in the context of mid-facial growth and development, as well as aspects linked to ethnic/racial characteristics, age, weight, and the tools used [48].
The procedure takes very little time and is performed at baseline and after vasoconstriction. Multiple sound stimuli are sent through the sonic tube while the patient is in apnea. Incorrect positioning and inclination of the sonic tube are the major source of errors (Figure 3C). AcR is much better than AARMN for the nasal provocation test, since it measures the volume and minimum transverse area (MTA) of the nasal passages quickly, directly, simply, and with high sensitivity and specificity $[42,49,50]$.

The most important information in AcR is obtained in the first $5 \mathrm{~cm}$ and essentially in the first $3 \mathrm{~cm}$ of the nasal fossa. There are 2 notches or narrower areas on the graph (Figure 3D).

The first notch or I-notch is in the nasal vestibule. Since it has no anatomical correlation, it is strictly accepted as an AcR measure. The absence of nasal mucosa at this point means that it will not be modified by vasoconstrictors [51].

The second notch, or C-notch, is located $1.83 \mathrm{~cm}$ (on average) from the nostril, with an average section of $0.56 \mathrm{~cm}^{2}$ in a nondecongested nasal cavity, and is anatomically correlated with the head of the inferior turbinate. The narrowest section (MTA) in healthy white individuals corresponds to the second notch (Figure 3D) and is the AcR measure of greatest clinical value; its average value in a normal nondecongested nostril is $0.56 \mathrm{~cm}^{2}[46,48,51]$. In whites, an MTA $<0.4$ at baseline correlates with NO [48]. Volume values can be obtained in the nasal passages at various distances from the nostril: the volume between $2 \mathrm{~cm}$ and $5 \mathrm{~cm}$ in the nasal cavity is the most sensitive measurement for showing changes in nasal permeability after decongestion of the nasal mucosa [52].

The result of the nasal provocation test is considered positive if the MTA and/or the nasal volume between $2 \mathrm{~cm}$ and $5 \mathrm{~cm}$ decreases by at least 25\%-30\% [44].

AARMN and AcR provide useful nasal permeability data based on the study of flow and of nasal geometry. These techniques are complementary [53].

PNIF. Like RMN, PNIF is a measurement of nasal permeability that provides nasal flow data expressed in liters per minute. It can be obtained by means of an inspiratory maneuver (PNIF) or forced expiration (PNEF) [54]. Both techniques correlate and are useful in measuring nasal flow [55]. As PNIF seems to correlate better with nasal resistance and given the possible contamination of the PNEF meter by secretions, the use of PNIF is more generalized [56].

Table 3. Grading of the Severity of Nasal Obstruction Based on Strictly Rhinomanometric Criteria

\begin{tabular}{lcccc}
\hline AARMN GROUPS & $\begin{array}{c}\text { Total Flow, mL/s } \\
\text { (Male) }\end{array}$ & $\begin{array}{c}\text { Total Flow, mL/s } \\
\text { (Female) }\end{array}$ & $\begin{array}{c}\text { Unilateral Flow, mL/s } \\
\text { (Male) }\end{array}$ & $\begin{array}{c}\text { Unilateral Flow, mL/s } \\
(\text { Female) }\end{array}$ \\
\hline Normal & $>700$ & $>630$ & $>350$ & $>315$ \\
Mild NO & $600-699$ & $530-629$ & $300-349$ & $265-314$ \\
Moderate NO & $500-599$ & $430-529$ & $250-299$ & $215-264$ \\
Severe NO & $300-499$ & $230-429$ & $150-249$ & $115-214$ \\
Very severe NO & $<299$ & $<229$ & $<149$ & $<114$
\end{tabular}

Abbreviations: AARMN, anterior active rhinomanometry; NO, nasal obstruction. 

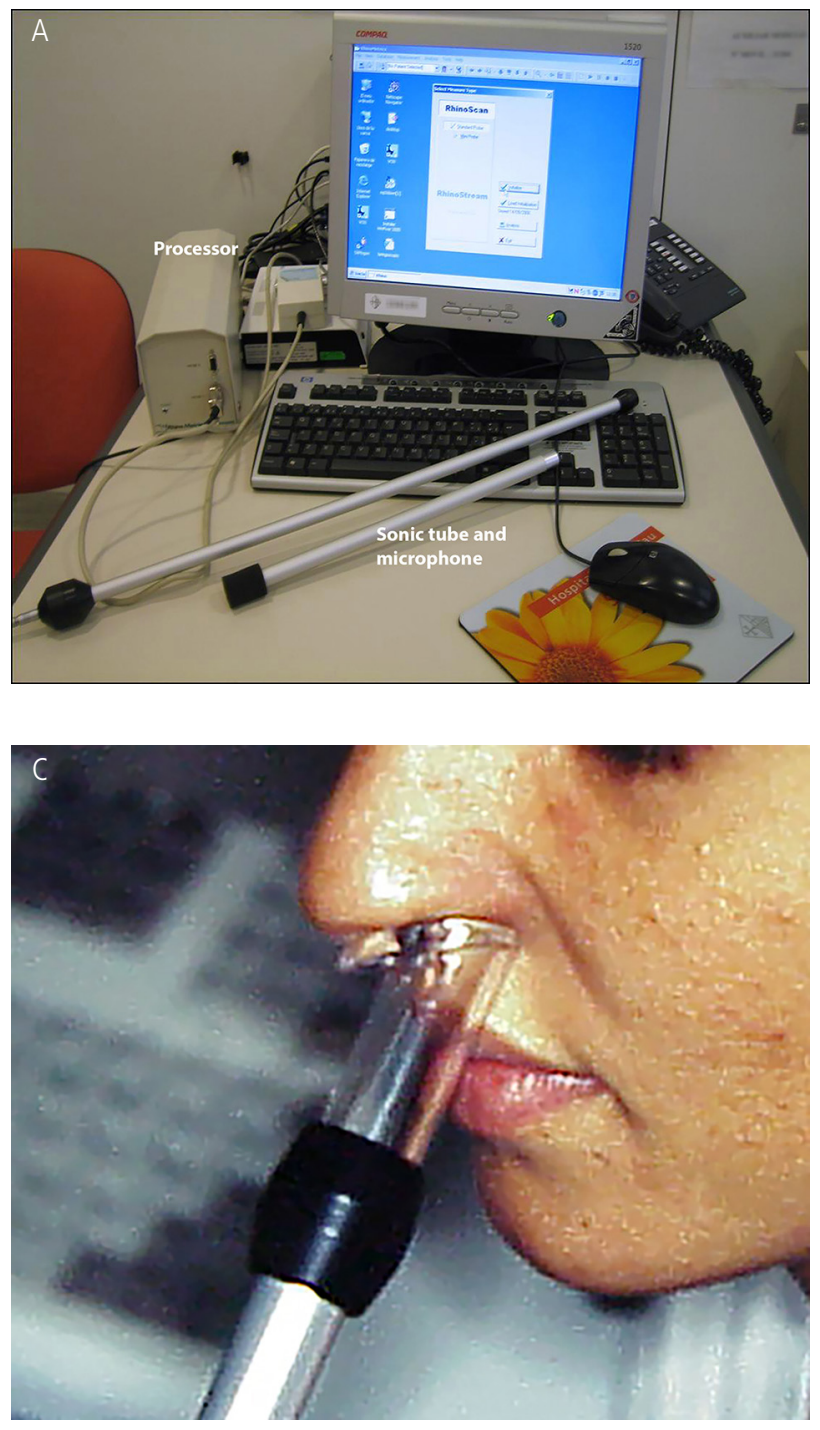
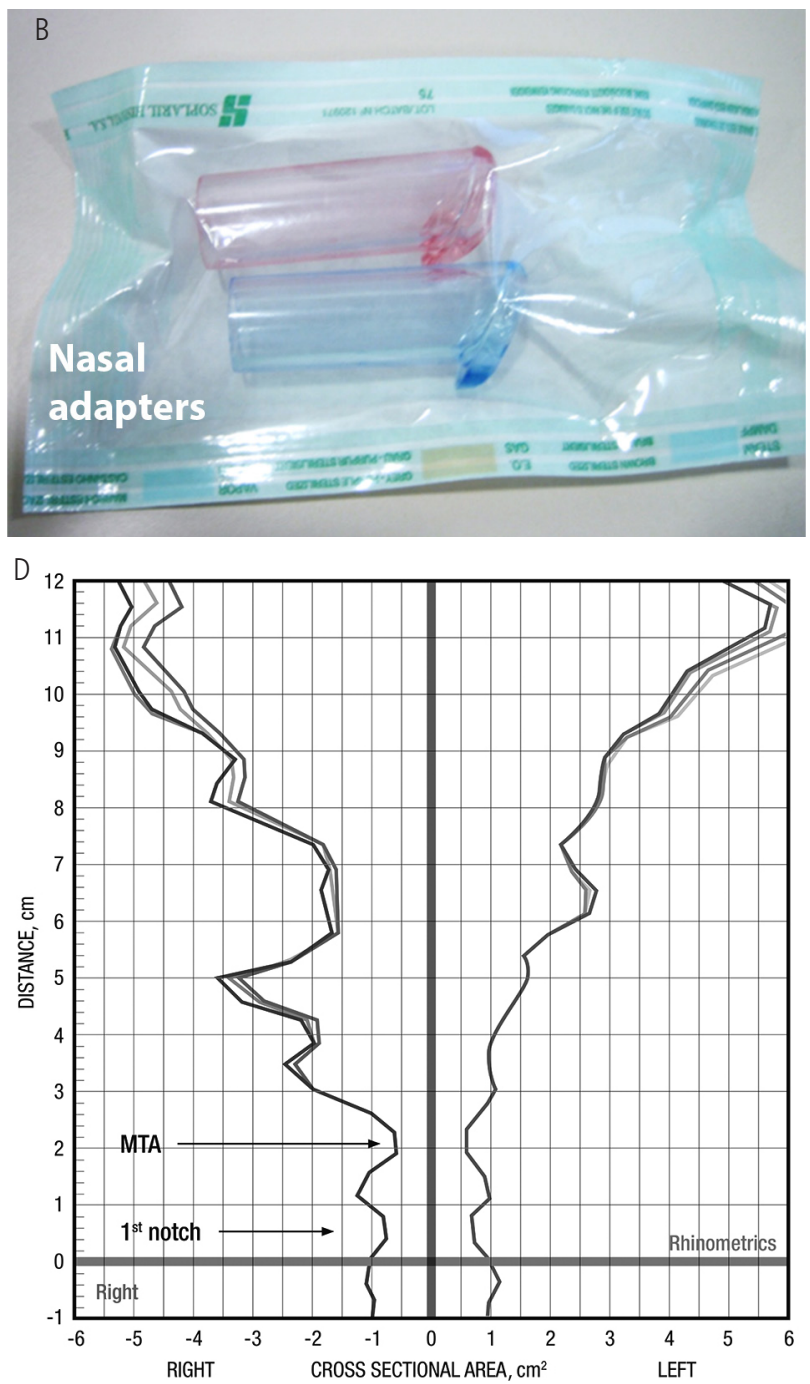

Abbreviations: MTA, minimum transverse area.

Figure 3. Acoustic rhinometry. A, Basic elements. Microphone located in the sonic tube. B, Nasal adapters. C, An intermediate piece or adapter is applied in the nasal window, which in turn is connected to the sonic tube. The adapter has a constant and pre-set length and section. D, The results obtained are recorded on a graph, where the areas are highlighted according to the distance from the nasal window. An integral provides information on volume. Two notches can be seen in the nondecongested nasal fossa. The narrowest area of the nasal cavity is usually located less than $3 \mathrm{~cm}$ from the nasal window.

PNIF is a simple and rapid technique that is carried out using a portable device. Measurement and interpretation do not require sophisticated equipment. The portable device is a plastic tube $(20 \mathrm{~cm}$ long, $3-4 \mathrm{~cm}$ in diameter, and calibrated at $30-370 \mathrm{~L} / \mathrm{min}$ ) to which a face mask is attached (Figure 4). From an expiratory maneuver to residual volume, a forced inspiration is made while the lips are sealed. Three measurements that must not vary by more than $10 \%$ are taken, and the best one is chosen [57]. The nasal cavity and the device must be clean, the mask must be correctly fitted without being deformed, and the maneuver must be carried out with the proper effort. Its usefulness in clinical practice lies in the fact that it is the only method available for home monitoring.

Measurements cannot be taken if nasal collapse occurs or when there are very serious obstructions [54]. A wide range of values of normality have been published in adults
[31,44,58-61] and children [58-61]. In general, values are higher in men than in women and are proportional to height; they increase from childhood to adulthood and then decrease in the elderly $[57,62]$.

Cut-off values of $115-120 \mathrm{~L} / \mathrm{min}$ have been suggested to distinguish normality from obstruction $[31,57,63,64]$, although there are no absolute values of normality and the patient is the best judge for evaluating changes.

The measurement of unilateral PNIF may be useful in the preoperative assessment of unilateral obstruction, such as septal deformity [65].

PNIF is closely related to maximum expiratory flow $[58,63,66,67]$, since a low quotient could correspond to an increase in bronchial resistance rather than a decrease in the PNIF. Its relationship with the symptom score measured using a VAS is controversial $[31,63,68,69]$, although it seems 


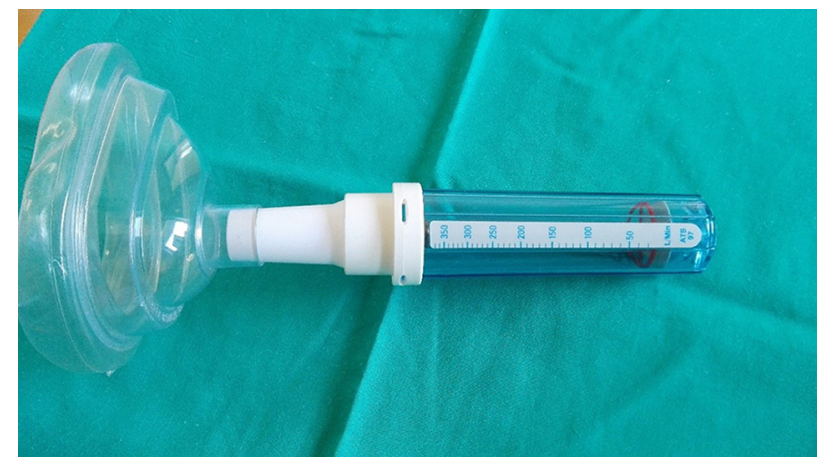

Figure 4. Portable device for measuring peak nasal inspiratory flow (PNIF).

to improve when compared with validated questionnaires such as the Sino-Nasal Outcome Test (SNOT-22) and NOSE [65,68,70-73].

Some studies consider it as sensitive as AcR in both allergenspecific and nonspecific nasal provocation tests $[31,74]$. Its ability to discriminate healthy individuals from patients is similar to that of AARMN $[31,75]$.

In nasal provocation, $\mathrm{a} \geq 40 \%$ reduction in PNIF is considered positive $[44,76,77]$.

\section{Other Techniques}

Data on nasal spirometry are scarce [78]. Other permeability assessment techniques, such as computational analysis of nasal fluid dynamics from simulations on computed tomography, are expensive and still not widely used $[79,80]$.

\section{Correlation Between Subjective and Objective Methods in Evaluating NO}

\section{How Subjective Methods Are Correlated}

Yepes-Nuñez et al [31] evaluated NO subjectively in 184 volunteers using VAS and a symptom scale. The correlation found between these subjective methods was moderate $(\mathrm{r}=0.68)$. In another study that evaluated NO both objectively and subjectively in 2 groups of patients (some treated with surgery and others treated with topical corticosteroids), a strong correlation $(\mathrm{r}=0.8)$ was detected between the 2 subjective tests used, namely, NOSE and VAS [81].

Despite these studies not being designed for purpose, the data lead us to affirm that there is a moderate to strong correlation between subjective methods for evaluating NO.

\section{How Objective Methods Are Correlated}

In most studies, the objective methods used are AARMN, AcR, and PNIF.

A study conducted in 65 patients with NP revealed a significant but weak inverse correlation $(r=0.29)$ between PNIF and polyp size based on endoscopic findings [82]. Another study evaluated the correlation between different variables of the AARMN and the AcR [31]. A moderate correlation was detected between the MTA value and resistance, although correlations between the other variables were weak. PNIF was moderately correlated with AcR $(\mathrm{r}=0.45)$ and weakly correlated with AARMN $(r=0.25)$.

These results reinforce the idea that the various objective methods measure specific aspects of NO and are therefore not comparable but complementary.

\section{How Subjective Methods and Objective Methods Are Correlated}

Several publications aim to correlate objective and subjective methods; however, the fact that these methods are not standardized means that there are differences in the study designs. The results of the studies considered most relevant are summarized below.

Lamb et al [83] used AcR, PNIF, NOSE, and VAS to evaluate NO in patients who came to the clinic for another reason (suspicion of obstructive sleep apnea syndrome). No significant correlation was detected between the objective and subjective measures used.

A moderate correlation was detected between the endoscopic size of the polyps and the evaluation of NO by VAS [82] in patients with NP.

Mendes et al [84] used AARMN, AcR, and a symptom scale in children with AR and healthy controls both globally and in each nostril separately. No significant correlation was detected between the objective and subjective methods used.

Weak correlations have been reported $(\mathrm{r}<0.4)$ between the methods used (AARMN, AcR, PNIF, VAS) [31].

Menger et al [72] evaluated the usefulness of MTA using computed tomography (CT) when comparing it with AARMN, AcR, and PNIF, as well as with the NOSE questionnaire in patients who were to undergo valve surgery because of alar collapse during inspiration. Significant correlations were detected between MTA-CT and NOSE and between PNIF and NOSE. No correlation was found between the subjective method used (NOSE) and AARMN or AcR [72].

A study that evaluated NO in children using nasal endoscopy, AcR, and VAS did not detect any significant correlation between the techniques, while a weak correlation was found between endoscopic findings (unilateral, bilateral, or absent obstruction) and VAS [34].

A very weak correlation $(\mathrm{r}=0.07)$ has been reported between AARMN and the NOSE questionnaire, and also with VAS ( $\mathrm{r}=0.09)$ [81].

Finally, Mozzanica et al [85] evaluated nasal permeability using NOSE, VAS, and AARMN in patients treated for NO and demonstrated weak to moderate correlations between the objective and subjective methods, with the highest correlation $(\mathrm{r}=0.54)$ detected between unilateral resistance and the second item of the NOSE.

In view of these results, we conclude that according to the studies reviewed, no correlation can be established between the objective and subjective methods used for evaluating NO. As any correlation observed is weak, we must consider these methods complementary and not exclusive.

\section{Quality of Life and NO}

The effect of NO on the nasal passage reduces QOL both in patients with AR $[86,87]$ and in patients with CRS with/ 
without NP [88-91] and leads to structural alterations of the nasal cavity $[92,93]$. Deterioration of QOL affects all age groups [94].

The impact of AR on QOL is well documented [95]. Some studies show a good correlation between the degree of NO determined using a validated questionnaire (CQ7) and specific QOL parameters in patients with AR [36]. However, other studies conducted in the primary care setting find little correlation between the intensity of NO measured by the symptoms scale and specific QOL questionnaires in AR (assessed using the Rhinoconjunctivitis Quality of Life Questionnaire [RQLQ]) [87].

AR exerts a negative influence on the quality of sleep, which undoubtedly has an impact on QOL, daily activities, and learning [96]. NO is one of the most annoying symptoms of rhinitis and is a key factor affecting sleep quality [97]. A large-scale Spanish study found that $53 \%$ of patients with AR slept badly and $21 \%$ experienced excessive daytime sleepiness, with obstruction, rhinorrhea, and pruritus being the factors that best correlated with these observations [98]. Moreover, if NO is specifically measured with validated instruments (NOSE questionnaire, CT scan, and nasal endoscopy) in patients with CRS, the correlation between NO and sleep quality is also significant, although weak [99].

On the other hand, effective treatment of NO can reduce the daytime sleepiness resulting from sleep disturbances in AR [100]. Similar effects can be observed in CRS [101-103].

The QOL questionnaires most used in AR (Table 4 [35,36,86,104-112]) are the RQLQ (validated in Spanish [109]) and the ESPRINT (Spanish QOL questionnaire for rhinitis), which was developed and validated in Spanish for the Spanish population [113] and has reference values based on the severity of AR [114]. It is the instrument of choice for the Spanishspeaking population [86]. Both correlate well with symptom counts, but only the RQLQ has shown a significant correlation with NO [109].

As for CRS (Table 4), SNOT-22 stands out because of its usefulness, although the Rhinosinusitis Disability Index, the Questionnaire of Olfactory Disorders, and the Sinusitis Control Test [88] have also been validated. The symptoms that most contribute to the deterioration of QOL appear to be otic or facial pain and sleep disturbance [101]. On the other hand, nasal symptoms do not seem to correlate well with the cognitive impairment observed for CRS [115]. The EuroQOL-5 Dimensions (EQ-5D) is the most commonly used generic questionnaire [88]. Other questionnaires not specifically designed to assess obstruction, such as NOSE [35] and CQ7 [36], also address QOL-related issues.

An important aspect of QOL is the calculation of "utility values" extracted from the EQ-5D questionnaire and used to calculate quality-adjusted life years, which is a numerical value that ranges between 0 and 1 ( 1 corresponds to the best possible state of health) and in allergic respiratory diseases varies between 0.60 and 0.85 [116]. In this sense, respiratory diseases resemble other chronic diseases such as diabetes, kidney failure, and chronic liver disease [116].

The high costs of AR are well known [95,116], with indirect costs being higher and doubling or tripling direct costs.

Table 4. Questionnaires and Scales Commonly Used in Allergic Rhinitis and Chronic Rhinosinusitis (Modified From Rudmik et al [88] and Meltzer et al [95])

\begin{tabular}{|c|c|c|c|c|}
\hline Acronym & Range & $\begin{array}{l}\text { Score } \\
\text { Range }\end{array}$ & $\begin{array}{l}\text { Spanish } \\
\text { Validation }\end{array}$ & Observations \\
\hline CQ7 [36] & 7 & $0-28$ & Yes & Specific questionnaire for measuring nasal obstruction \\
\hline NOSE [35] & 5 & $0-100$ & Yes & $\begin{array}{l}\text { Specific questionnaire for assessing symptoms in patients } \\
\text { with nasal obstruction }\end{array}$ \\
\hline EQ-5D [104] & 15 & $0-100$ & Yes & QOL generic questionnaire that allows calculation of QALY \\
\hline SF-36 and SF-12 [105] & $36 / 12$ & $0-100$ & Yes & QOL generic questionnaires for comparison with other conditions \\
\hline RSDI $[106]$ & 30 & $0-120$ & Yes & Used occasionally to evaluate QOL in nasal polyposis \\
\hline RSOM-31 [107] & 31 & $0-155$ & Yes & Used occasionally to evaluate QOL in nasal polyposis \\
\hline SNOT-22 [108] & 22 & $0-110$ & Yes & The most widely disseminated questionnaire for QOL in CRS \\
\hline RQLQ, Mini-RQLQ [109] & $28 / 12$ & $0-168 / 72$ & Yes & $\begin{array}{l}\text { The most widely used international questionnaire for QOL in } \\
\text { allergic rhinitis }\end{array}$ \\
\hline ESPRINT-15 [86] & 15 & $0-60$ & Yes & $\begin{array}{l}\text { Specifically developed in Spanish and validated in the Spanish } \\
\text { population. Recommended by the authors to evaluate QOL in } \\
\text { allergic rhinitis in Spanish-speaking populations. }\end{array}$ \\
\hline RhinAsthma [110] & 42 & $0-100$ & No & Joint evaluation of QOL in rhinitis and asthma \\
\hline QOD [111] & 25 & $0-57$ & No & Specific questionnaire that evaluates the sense of smell \\
\hline PSQI [112] & 19 & $0-21$ & Yes & Used to evaluate sleep quality \\
\hline
\end{tabular}

Abbreviations: CQ7, Congestion Quantifier Seven-Item test; CRS, chronic rhinosinusitis; EQ-5D, EuroQol Group. EuroQol; ESPRINT-15, ESPRINT-15 Questionnaire; NOSE, Nasal Obstruction Symptom Evaluation; PSQI, Pittsburgh Sleep Quality Index; QALY, quality-adjusted life year; QOD, Questionnaire of Olfactory Disorders; QOL, Quality of Life; RhinAsthma, Specific QOL questionnaire for patients with rhinitis and asthma; RQLQ, Rhinoconjunctivitis Quality of Life Questionnaire; RSDI, Rhinosinusitis Disability Index; RSOM-31, 31-Item Rhinosinusitis Outcome Measurement; SNOT-22, Sinonasal Outcome Test. 
Presenteeism (loss of productivity while in the workplace) is very high in AR patients, surpassing that of other chronic diseases such as diabetes [117]. According to a study carried out in Spain [118], the total cost of AR per patient per year (treatment by a specialist) reaches $€ 2327$ (direct, $€ 554$; indirect, $€ 1773$ ). However, no specific data are available on the direct influence of the degree of NO on the amount of these costs, although significant differences have been established depending on severity, especially with regard to indirect costs [118].

Therefore, we can conclude that both AR and CRS imply appreciable impairment of QOL and sleep quality. These conditions also generate high costs, which are related to severity and persistence, and the intensity of the symptoms, including NO, plays an important role.

\section{Medical Treatment (Table 5)}

In this case, the search methodology was based on providing the maximum scientific evidence while including systematic reviews and meta-analyses (level of evidence, Ia).

\section{Nasal decongestants}

Both oral decongestants (ephedrine, phenylephrine, phenylpropanolamine, and pseudoephedrine) and intranasal decongestants (phenylephrine, naphazoline, oxymetazoline, tramazoline, xylometazoline) have proven to be effective in treating NO associated with AR and CRS with NP (Table 5). They reduce sinusoid blood-flow, improve permeability, and

Table 5. Grading of the Severity of Nasal Obstruction Based on Strictly Rhinomanometric Criteria

\begin{tabular}{lcc}
\hline & Allergic Rhinitis $^{\mathrm{a}}$ & CRS With NPa \\
\hline Antihistamine $\mathrm{H}_{1}$ & & \\
$\quad$ Intranasal & + & 0 \\
$\quad$ Oral & + & 0 \\
Corticosteroid & +++ & +++ \\
$\quad$ Intranasal & ++++ & ++++ \\
Oral & ++++ & $\mathrm{NS}$ \\
MP-AzeFlu & + & + \\
Chromones & & \\
Nasal decongestants & +++++ & + \\
$\quad$ Intranasal & +++ & ++ \\
Oral & ++ & + \\
Antileukotriene & + & 0 \\
Allergen immunotherapy & ++ & ++++ \\
Biologics & + & ++ \\
Nasal saline solution & &
\end{tabular}

aDecongestive efficacy: very high $(+++++)$, high $(++++)$, quite high $(+++)$, moderate $(++)$, little $(+)$, null $(0)$, no studies (NS). Abbreviations: MP-AzeFlu: intranasal formulation of azelastine hydrochloride (anti- $\left.\mathrm{H}_{1}\right)$ and fluticasone propionate (corticosteroid) nasal spray. decrease resistance to passage of air. However, the adverse effects of prolonged use of these drugs not only produce drug-induced rhinitis and organic nasal lesions, but may also be responsible for serious systemic alterations [119-124]. Therefore, their use, dose, frequency, and duration should be restricted.

Rhinitis. One systematic review showed that a single intranasal dose significantly improved acute nasal congestion and reduced nasal airway resistance in adults with common cold [125]. A meta-analysis also demonstrated this effect with oral administration of phenylephrine [126].

Rhinosinusitis. Several systematic reviews have not provided sufficient scientific evidence to justify recommending the use of nasal decongestants in acute rhinosinusitis (ARS) or CRS [127].

\section{Corticosteroids}

Intranasal corticosteroids (INCs) (beclomethasone, budesonide, ciclesonide, fluticasone propionate, fluticasone furoate, mometasone, triamcinolone) have a potent antiinflammatory effect and have proven to be effective in treating NO in both rhinitis and rhinosinusitis, as shown in several international consensus statements [127-131]. Corticosteroids decrease inflammatory infiltrate and vascular permeability [132].

Rhinitis. One systematic review highlights the lack of evidence to support their use in NO caused by the common cold [133]. However, INCs are the most effective medication for treating AR $[129,134]$ and have proven to be more effective than other medications. They are also the first-line drugs for treating NAR [135].

Oral corticosteroids (OCs) (prednisone, methylprednisolone, deflazacort) have an even more potent effect on NO, with predominance over the nonvascular component, both in AR and in moderate-severe NAR compared with placebo. Given the risk of adverse effects caused by prolonged use, OCs are not indicated as primary treatment, but for controlling exacerbations when the usual medical treatment fails.

Rhinosinusitis. International consensus statements [127,130] recommend the use of INCs for both ARS and CRS with NP or CRS without NP. They improve NO, as well as edema, polyp size [136,137], and recurrence after surgery [138]. In CRS with NP, administration in droplets has proven to be more efficacious than spray [128]. There is no clear recommendation on prophylaxis of recurrent ARS.

OCs are effective in improving NO and reducing the size of nasal polyps $[139,140]$, although they should be reserved for the short-term treatment of the most severe, uncontrolled cases [141].

\section{$H_{1}$ Antihistamines}

Second-generation $\mathrm{H}_{1}$ antihistamines (anti- $\mathrm{H}_{1}$ ) - both oral agents (bilastine, cetirizine, desloratadine, ebastine, fexofenadine, levocetirizine, loratadine, mequitazine, mizolastine, rupatadine) and intranasal agents (azelastine, levocabastine, olopatadine) - exert their antiallergic effects as inverse agonists of the $\mathrm{H}_{1}$ receptor. 
Rhinitis. Both oral and intranasal anti- $\mathrm{H}_{1}$ have shown efficacy in NO in patients with AR $[142,143]$, although the magnitude of the benefit is modest compared with decongestants and INCs [144].

Rhinosinusitis. Some improvement in NO has been described in patients with NAR or rhinosinusitis, but the evidence is very weak, with the result that anti- $\mathrm{H}_{1}$ are not recommended except in cases of concomitant AR [130]. Similarly, there is no evidence of efficacy in the common cold [145].

\section{Intranasal formulation of fluticasone + azelastine (MP-AzeFlu)}

Initial studies suggest that the action that explains the superior clinical effect of MP-AzeFlu is based on a greater reduction in proinflammatory mediators [146] combined with greater stimulation of anti-inflammatory genes [147].

Rhinitis. The efficacy of MP-AzeFlu has been shown to be superior to INCs and intranasal anti- $\mathrm{H}_{1}$ monotherapy in patients with moderate-severe, poorly controlled AR or NAR [148-150].

Rhinosinusitis. Except for models of eosinophilic inflammation in vitro [146,147], no studies have been performed.

\section{Antileukotrienes}

Leukotrienes are inflammatory mediators present in AR and CRS with NP and are partly responsible for chronic NO. Therefore, antileukotriene drugs (montelukast, zafirlukast) may improve NO.

Rhinitis. The effect on NO in monotherapy is weaker than that obtained with INCs; therefore, it is not advised [151,152]. Antileukotrienes have been shown to be more effective than anti- $\mathrm{H}_{1}$ against the nocturnal symptoms of AR (including NO) but not against diurnal symptoms [153]. Combination with anti- $\mathrm{H}_{1}$ is not recommended, given that few efficacy tests have been conducted on these drugs in monotherapy.

Rhinosinusitis. There is insufficient evidence to recommend the use of antileukotrienes for treating NO in CRS with NP [154]. In patients with aspirin-exacerbated respiratory disease (AERD) or patients taking nonsteroidal anti-inflammatory drugs, their benefit may be limited [127].

\section{Intranasal chromones}

Intranasal chromones (cromoglycate, nedocromil) act on sinonasal inflammation mainly by stabilizing mast cells. Their effect on NO in AR is marginal and inferior to that of INCs [129]. Efficacy has not been demonstrated in patients with CRS and NP [130].

\section{Anticholinergics}

Activation of the parasympathetic system causes vasodilation and hypersecretion of the nasal mucosa, which is responsible in part for NO and may potentially improve with intranasal anticholinergics (ipratropium bromide). However, one systematic review has shown some effect on controlling rhinorrhea but none on NO in the common cold or on AR and NAR [155].

\section{Other medications}

Capsaicin (the spicy component of pepper) is a neurotoxin that stimulates the nerve endings so that they release substance $\mathrm{P}$ and other neuropeptides involved in the neurogenic inflammation present in rhinitis and rhinosinusitis. Although it is considered a therapeutic option in NAR, there is no evidence for its use in NO caused by AR and CRS [156,157].

Lysine acetylsalicylate has been used topically in soluble form to desensitize aspirin in patients with AERD. In progressive doses and administered together with INCs, there is a certain clinical benefit in which NO is improved and the size of the NP is reduced [158].

In several controlled studies in children and adults with rhinitis or rhinosinusitis, nasal washes or showers with saline solution (isotonic or hypertonic), have proven to improve NO $[159,160]$. A recent meta-analysis supports its use in the treatment of CRS with NP [161] both before and after surgery. It is recommended in volumes greater than $200 \mathrm{~mL}$ and can be used concomitantly with INCs $[127,130]$.

There is no scientific evidence of the efficacy of other treatment options, such as menthol, mucolytics, furosemide, and proton pump inhibitors, with the result that they are not recommended [162]. Intranasal Cyclamen europaeum has shown some efficacy against NO in ARS [163].

\section{Avoidance of allergens and irritants}

Environmental control measures aim to reduce or eliminate allergens and irritants to obtain clinical benefits in patients with AR and/or rhinosinusitis, especially in those whose exposure correlates with the onset of naso-ocular symptoms [134]. However, the available data tend to be global and do not specifically address improvement in NO. In pet allergies, the most effective measure is to remove the animal from the patient's environment. Although individualized actions aimed at reducing exposure show no reduction in AR symptoms, combined and maintained measures do not ensure a clear clinical benefit either [164]. In AR caused by mites, interventions to reduce allergenic exposure may improve $A R$ symptoms [165], although combined actions (antimite mattress covers, acaricide, high-efficiency particulate air filters) and continuous actions are also necessary.

\section{Immunotherapy}

AR. Allergen-specific immunotherapy (AIT) should be offered to AR patients who do not respond sufficiently well to pharmacological treatment, with or without environmental control measures $[134,166]$. AIT modifies the natural history of the disease, improves naso-ocular symptoms (NO included), and reduces the need for medical treatment. In the long term, it can improve or prevent asthma and conjunctivitis, improve QOL, and prevent the development of new sensitizations to aeroallergens [134,167]. Both subcutaneous immunotherapy (SCIT) [168] and sublingual immunotherapy (SLIT) [169,170] have proven effective in reducing the symptoms (including NO) of seasonal and perennial AR [171].

Total symptom score is the main variable in systematic reviews and meta-analyses, both in SCIT [172] and in SLIT 
in drops [173] or in tablets [174]; therefore, specific data on NO are not usually published [171]. In a review of clinical trials conducted using grass pollen tablets in a pre/coseasonal pattern, a reduction was observed compared with placebo in children (31\%) and adults (43\%) with AR [175]. Moreover, in a clinical trial performed with mite tablets in mild or moderate AR, NO improved significantly compared with placebo [176].

Local allergic rhinitis. A clinical trial with mite SLIT demonstrated relief of nasal symptoms in addition to a negative nasal provocation result in $50 \%$ of patients with local allergic rhinitis [177].

$C R S$. A recent systematic review assessed the clinical efficacy of AIT in patients with CRS with and without NP and in patients with allergic fungal rhinosinusitis. The conclusions were very limited owing to the scarcity of available data. In addition, efficacy tests do not support its use in CRS [178].

\section{Biological therapy}

These are humanized or human monoclonal antibodies that are mostly administered subcutaneously and aimed at blocking specific sinonasal inflammatory targets.

Rhinitis. Omalizumab (free anti-IgE) has demonstrated its efficacy in AR [179], although it is not authorized for this disease.

Rhinosinusitis. A series of monoclonal antibodies have been administered against different targets in phase 2 or 3 studies for the treatment of moderate-severe CRS with NP that are resistant to treatment with INCs. These include omalizumab [180], dupilumab (anti-IL-4R $\alpha$ [181]), mepolizumab (free antiIL-5 [182]), reslizumab (free anti-IL-5 [183]), benralizumab (anti-IL-5R $\alpha$ [184]), and AK-001-002 (anti-siglec8 [185]). These biological treatments have a potentially major effect on NO and the size of NP.

\section{Surgical treatment}

Managing NO requires a correct diagnosis, medical treatment, and, in some cases, surgical treatment when medical treatment fails to improve the condition or in those cases where another therapeutic approach is impossible. Scientific evidence in favor of surgery is generally less robust than for pharmacological approaches (owing to the difficulty in reducing variability in the technique or evaluating outcome with double control groups). The methodology of studies on surgical innovations must be improved [186,187].

Surgical treatment depends on etiology. Consequently, it is often necessary to combine several techniques in the same patient, and subsequent medical treatment may be necessary.

In certain cases of rhinitis with turbinate hypertrophy, surgical treatment has been shown to improve nasal permeability when pharmacological treatment maintained for at least 3 months has failed [134,188-190]. Numerous turbinoplasty procedures have been described $[191,192]$. For many years, intramucosal volume has been reduced using techniques such as radiofrequency [193-198], ultrasound [199], cryosurgery [198] and laser vaporization [200,201]. These techniques are well tolerated, can be performed without general anesthesia, have few complications, and are widely used, although their effectiveness tends to decrease over time [202]. In procedures that act by excising mucosa and turbinate bone (partial turbinectomy, submucosal resection [203]), the risk of complication seems somewhat higher [191,204,205], although the results may be better [193,205-209]. Fracture/dislocation of the inferior turbinate $[210,211]$ is used in combination with other techniques for cases where the turbinate is increased by the bone component.

In CRS with NP, endoscopic surgical treatment has been shown to be beneficial in patients with severe symptoms who do not respond to appropriate medical treatment $[20,127,128,212-218]$ and may be more cost-effective $[219,220]$. The delay in surgery can negatively influence postoperative results and healthcare costs [221], although more studies are necessary to confirm this observation [218]. A short course of systemic corticosteroids improves surgery [222]. While radical surgery seems to obtain better results [223], the extent of the intervention remains unclear [224]. In recurrences, more aggressive surgery may be indicated [225]. Treatment with INCs should continue after surgery [226], and very long-term control leads to improvement [227]. Surgery may be beneficial in patients with NP with associated asthma [228,229], AERD [230], or cystic fibrosis [231-233]. Surgery is also indicated in CRS without NP that does not improve with medical treatment [20,234].

The collapse of the nasal valve, which leads to closure of the airway during inspiration, is a frequent and less well-known cause of NO $[235,236]$. Sometimes it occurs after rhinoplasty and septal or turbinate surgery [237]. The numerous techniques proposed to remedy this situation include grafting [238-243] (eg, spreader and batten grafts [244-248]), implants [249,250], and other procedures [251-256].

The mechanical or anatomical causes of NO can only be addressed with surgery. The endoscopic approach is replacing other approaches [257-259] in choanal atresia. Surgery is mandatory when choanal atresia is bilateral; treatment can be delayed in unilateral atresia. In septoplasty, surgical techniques vary depending on the complexity of the anatomical alteration in the nasal septum [260,261]. Septal perforations are also a cause of NO due to airflow alteration. Surgical techniques depend on the size and location of the obstruction [223,262-269].

In benign tumors such as inverted papilloma or juvenile angiofibroma, endoscopic treatment is usually the approach of choice and aims to achieve complete surgical resection [270]. In the case of malignant tumors, therapy should be designed on an individual basis, and decisions should be taken by an interdisciplinary tumor committee [270,271].

\section{Management of Patients With NO}

$\mathrm{NO}$ is frequently reported by patients in primary care and in specialized care. It has a huge impact on patients' QOL and especially on sleep quality. As it can be caused by various factors, a complete medical history and clinical examination are the main basis of its etiological diagnosis. Furthermore, although both the pattern and location can suggest the underlying disease, objective and subjective assessment tools are useful for evaluation of NO. As these techniques measure different aspects, they are complementary. Figures 5 and 6 summarize how to assess patients with NO. 
Finally, treatment must address the cause. Current therapeutic options include many topical and systemic drugs, although surgery is necessary in some cases.

\section{Key Points}

- NO is one of the most common reasons for consultation in primary and specialized care.

- NO can be caused by drugs and by anatomical, inflammatory, neurological, hormonal, functional, and environmental factors.

- Unilateral NO that progresses over time may be a sign that the disorder has its origin in a tumor.

- NO can be subjectively evaluated using a VAS, a symptom rating scale (eg, Likert-type), and/or a questionnaire to assess the effect of NO (NOSE, CQ7, or DyNaChron).
- NO can be objectively evaluated using techniques that assess nasal geometry (AcR) or nasal permeability (AARMN and PNIF).

- The objective techniques for evaluation of NO measure different aspects and are therefore not comparable but complementary.

- The objective and subjective methods for evaluation of NO do not correlate or do so very poorly; therefore, they should be considered complementary and not exclusive.

- NO affects the patient's QOL, especially sleep quality.

- NO should be treated according to its cause.

- Nasal decongestants have proven to be effective in treating NO associated with AR and NAR, but there is no evidence that this is the case in ARS or CRS. Given their adverse effects, use should be limited both in dosage and in time.
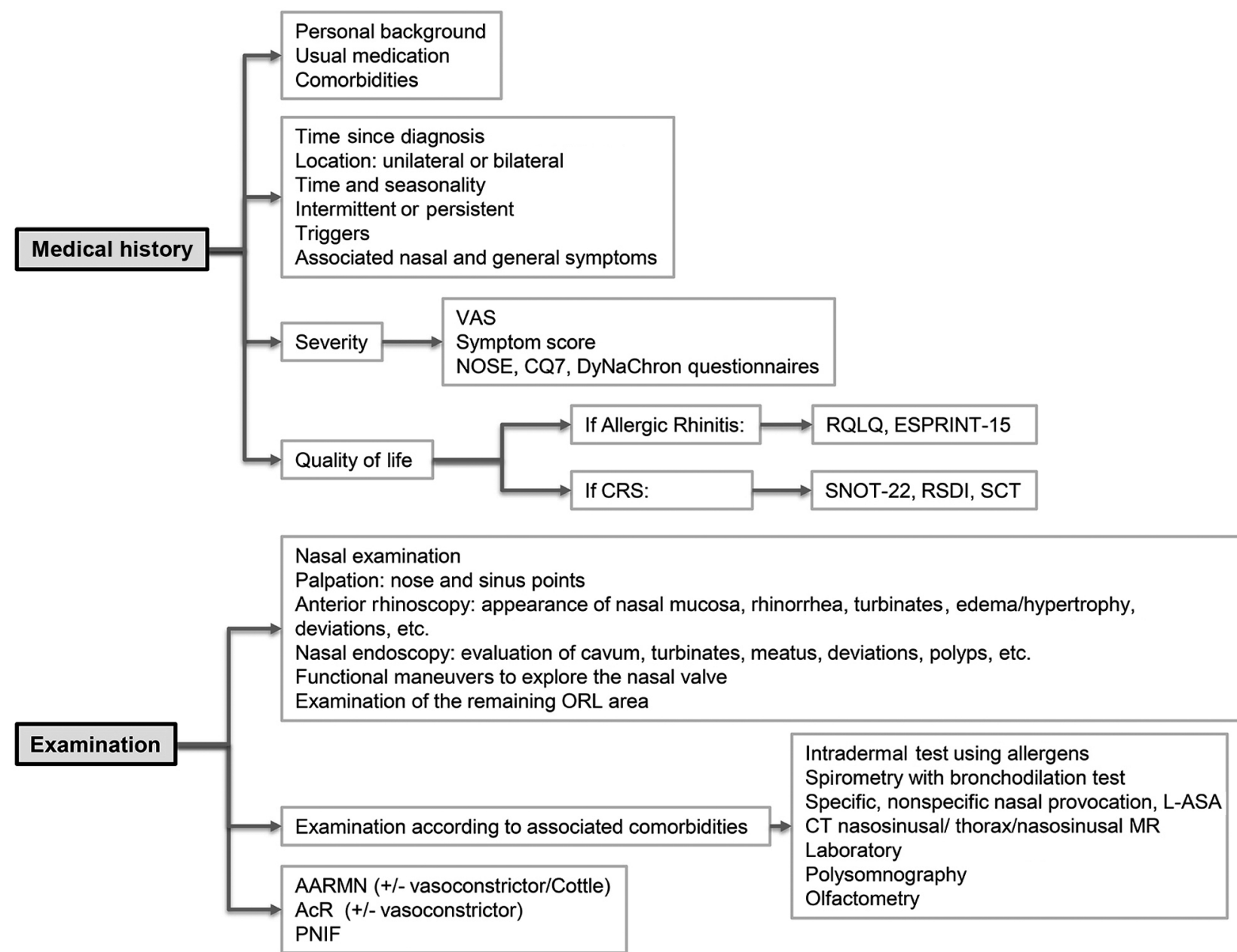

Abbreviations: AARMN, anterior active rhinomanometry; AcR, acoustic rhinometry; CQ7, Congestion Quantifier Seven-Item test; CRS, Chronic Rhinosinusitis; CT, computed tomography; ESPRINT-15, ESPRINT-15 Questionnaire; L-ASA, lysine acetylsalicylate; MR, magnetic resonance; NOSE, Nasal Obstruction Symptom Evaluation; ORL, otorhinolaryngologic; PNIF, peak nasal inspiratory flow; RQLQ, Rhinoconjunctivitis Quality of Life Questionnaire; RSDI, Rhinosinusitis Disability Index; SCT, Sinusitis Control Test; SNOT-22, Sinonasal Outcome Test; VAS, visual analog scale.

Figure 5. Algorithm for evaluating nasal obstruction. 


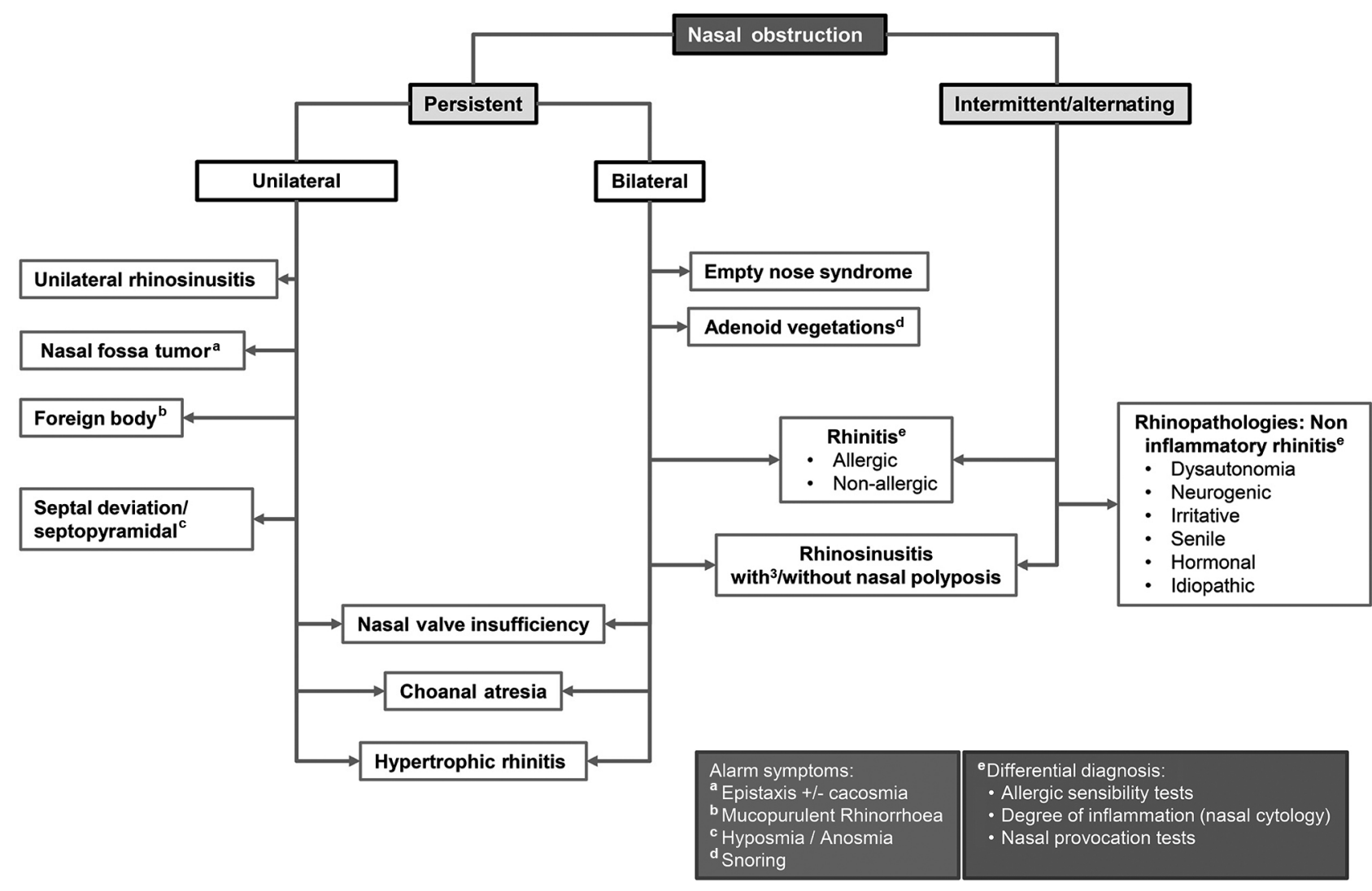

Figure 6. Algorithm for differential diagnosis of nasal obstruction.

- INCs have proven to be efficacious against NO in rhinitis and rhinosinusitis. Oral corticosteroids have a more potent effect, but they should not be indicated as first-line treatment, except for the control of exacerbations when routine medical treatment fails.

- Both oral and intranasal anti- $\mathrm{H}_{1}$ have proven effective against NO in patients with AR, although the benefit is modest compared with decongestants and INCs.

- The efficacy of the intranasal formulation MP-AzeFlu is superior to that of INCs and intranasal anti- $\mathrm{H}_{1}$ monotherapy in patients with moderate-severe, poorly controlled AR or NAR.

- Nasal washes or showers with saline solution (isotonic or hypertonic) improve NO in rhinitis and rhinosinusitis.

- Although AIT has an "A" recommendation for AR, there are no specific data for its effect on NO.

- Biological drugs may play a key role in improving NO associated with CRS and NP, although they are still in the clinical trial phase for this indication. There are also studies of efficacy in AR.

- Surgery may be necessary after medical treatment has failed, or when other therapeutic approaches are not possible. It will often be necessary to combine several techniques in the same patient or to combine these techniques with medical treatment before or after surgery.

\section{Acknowledgments}

The authors would like to thank Adelphi Spain for editorial assistance.

\section{Funding}

The present publication was funded by GSK. However, GSK was not involved in the design of the publication or in the selection of authors. Therefore, GSK is not responsible for and does not subscribe to the contents of the publication or freely expressed author statements.

\section{Conflicts of Interest}

Antonio Valero Santiago has participated in advisory boards and acted as a consultant for FAES Farma, Orion Pharma, Novartis, Uriach Pharma, Mylan Pharmaceuticals, and Stallergenes. He has received speaker's honoraria from Novartis, GSK, Stallergenes, Chiesi, Leti, Boehringer Ingelheim, Menarini, and Thermo Fisher and grant support from Novartis, FAES Farma, and Uriach Pharma.

Miguel Armengot Carceller is or has been a member of scientific advisory committees for ALK-Abelló and has received speaker's honoraria from MSD.

Ana María Navarro Pulido has participated in advisory boards and acted as a consultant for ALK-Abelló, Ferrer, GSK, 
MEDA, and Stallergenes. She has received speaker's honoraria from Allergy Therapeutics, Astra-Zeneca, FAES, GSK, Leti, Menarini, Merck, MSD, and Uriach.

Teresa Dordal Culla has received speaker's honoraria from ALK-Abelló and FAES Farma.

Carlos Colás Sanz has received funding for research projects and/or honoraria as a speaker for GSK, Menarini, MYLAN-MEDA, and Novartis.

Alfonso del Cuvillo Bernal has received funding for research projects, participated in advisory boards, acted as a consultant, and/or received honoraria as a consultant or speaker for ALK-Abelló, FAES, GSK, LETI, MSD, Menarini, MYLAN-MEDA, Novartis, UCB Pharma, and Uriach Group.

Joaquim Mullol i Miret is or has been a member of national and international scientific advisory committees (consultancy) and has received conference fees and fellowships for research projects from ALK-Abelló, FAES, Genentech, GSK, Menarini, MSD, MYLAN-MEDA, Novartis, SANOFI-GenzymeRegeneron, UCB Pharma, and Uriach Group.

Francisco Vega de la Osada has received speaker's honoraria from GSK, FAES, Chiesi, MSD, Bial, and Pfizer,

The remaining authors declare that they have no conflicts of interest.

\section{References}

1. Wever C. The Nasal Airway: A Critical Review. Facial Plast Surg. 2016;32:17-21.

2. Osborn JL, Sacks R. Chapter 2: Nasal obstruction. Am J Rhinol Allergy. 2013;27:7-8.

3. Shemirani NL, Rhee JS, Chiu AM. Nasal airway obstruction: allergy and otolaryngology perspectives. Ann Allergy, Asthma Immunol. 2008;101:593-8.

4. Migueis DP, Thuler LCS, de Andrade Lemes LN, Moreira CSS, Joffily L, de Araujo-Melo MH. Systematic review: the influence of nasal obstruction on sleep apnea. Braz J Otorhinolaryngol. 2016;82:223-31.

5. Toh S-T, Lin C-H, Guilleminault C. Usage of four-phase highresolution rhinomanometry and measurement of nasal resistance in sleep-disordered breathing. Laryngoscope. 2012;122:2343-9.

6. Derin S, Sahan M, Deveer M, Erdogan S, Tetiker H, Koseoglu S. The Causes of Persistent and Recurrent Nasal Obstruction After Primary Septoplasty. J Craniofac Surg. 2016;27:82830.

7. OCEBM Levels of Evidence Working Group. "The Oxford 2011 Levels of Evidence". Oxford Centre for Evidence-Based Medicine. http://www.cebm.net/index.aspx?0=5653.

8. Bayard MA, Algra P, Hyman LJ, Donaldson C. Improving your approach to nasal obstruction. J Fam Pract. 2016;65:889-99.

9. Stewart M, Ferguson B, Fromer L. Epidemiology and burden of nasal congestion. Int J Gen Med. 2010;3:37-45.

10. Baraniuk JN. Subjective Nasal Fullness and Objective Congestion. Proc Am Thorac Soc. 2011:8:62-9.

11. Al Suleimani $M$, Walker $M$. Allergic rhinitis and its pharmacology. Pharmacol Ther. 2007;114:233-60.

12. Patel R. Nasal Anatomy and Function. Facial Plast Surg. 2017;33:3-8.
13. Ogle OE, Weinstock RJ, Friedman E. Surgical Anatomy of the Nasal Cavity and Paranasal Sinuses. Oral Maxillofac Surg Clin North Am. 2012;24:155-66.

14. Houser SM. Surgical Treatment for Empty Nose Syndrome. Arch Otolaryngol Neck Surg. 2007;133:858.

15. González Pérez R. Test de provocación nasal con acetilsalicilato de lisina: nuevo método diagnóstico en la intolerancia a anti-inflamatorios no esteroideos (Tesis Doctoral). Tenerife: Universidad de La Laguna, 2004.

16. Eccles R. Mechanisms of the symptoms of rhinosinusitis. Rhinology. 2011;49:131-8.

17. Patuzzi R, Cook A. Acoustic impedance rhinometry (AIR): a technique for monitoring dynamic changes in nasal congestion. Physiol Meas. 2014;35:501-15.

18. Nathan RA. The pathophysiology, clinical impact, and management of nasal congestion in allergic rhinitis. Clin Ther. 2008;30:573-86.

19. Naclerio RM, Bachert C, Baraniuk JN. Pathophysiology of nasal congestion. Int J Gen Med. 2010;3:47-57.

20. Fokkens W, Lund V, Mullol J. European Position Paper on Rhinosinusitis and Nasal Polyps. Rhinology. 2012;1-136.

21. Van Spronsen E, Ingels KJ, Jansen AH, Graamans K, Fokkens WJ. Evidence-based recommendations regarding the differential diagnosis and assessment of nasal congestion: using the new GRADE system. Allergy. 2008;63:820-33.

22. Chandra RK, Patadia MO, Raviv J. Diagnosis of Nasal Airway Obstruction. Otolaryngol Clin North Am. 2009;42:207-25.

23. Rhee JS, Sullivan CD, Frank DO, Kimbell JS, Garcia GJ. A systematic review of patient-reported nasal obstruction scores: defining normative and symptomatic ranges in surgical patients. JAMA Facial Plast Surg. 2014;16:219-25; quiz 232.

24. Stull DE, Krouse J, Meltzer EO, Roberts L, Kim S, Frank L, et al. Development and Validation of the Congestion Quantifier Seven-Item Test (CQ7): A Screening Tool for Nasal Congestion. Value Heal. 2007;10:457-65.

25. Lötvall J, Ekerljung L, Lundbäck B. Multi-symptom asthma is closely related to nasal blockage, rhinorrhea and symptoms of chronic rhinosinusitis-evidence from the West Sweden Asthma Study. Respir Res. 2010;11:163.

26. Scadding GK, Scadding GW. Diagnosing Allergic Rhinitis Immunol Allergy Clin North Am. 2016;36:249-60.

27. Cingi $C$, Ozdoganoglu T, Songu M. Nasal obstruction as a drug side effect. Ther Adv Respir Dis. 2011;5:175-82.

28. Zambetti G, Filiaci F, Romeo R, Soldo P, Filiaci F. Assessment of Cottle's areas through the application of a mathematical model deriving from acoustic rhinometry and rhinomanometric data. Clin Otolaryngol. 2005;30:128-34.

29. Fung E, Hong P, Moore C, Taylor SM. The effectiveness of modified cottle maneuver in predicting outcomes in functional rhinoplasty. Plast Surg Int. 2014;2014:6.

30. Bloching MB. Disorders of the nasal valve area. GMS Curr Top Otorhinolaryngol Head Neck Surg. 2007;6:Doc07.

31. Yepes-Nuñez JJ, Bartra J, Muñoz-Cano R, Sánchez-López J, Serrano C, Mullol J, et al. Assessment of nasal obstruction: correlation between subjective and objective techniques. Allergol Immunopathol (Madr). 2013;41:397-401.

32. Kjaergaard $T$, Cvancarova $M$, Steinsvåg SK. Does nasal obstruction mean that the nose is obstructed? Laryngoscope. 2008;118:1476-81. 
33. Ciprandi G, Mora F, Cassano M, Gallina AM, Mora R. Visual Analog Scale (VAS) and Nasal Obstruction in Persistent Allergic Rhinitis. Otolaryngol Neck Surg. 2009;141:527-9.

34. Isaac A, Major M, Witmans M, Alrajhi Y, Flores-Mir C, Major $P$, et al. Correlations Between Acoustic Rhinometry, Subjective Symptoms, and Endoscopic Findings in Symptomatic Children With Nasal Obstruction. JAMA Otolaryngol Neck Surg. 2015; 141:550.

35. Larrosa F, Roura J, Dura MJ, Guirao M, Alberti A, Alobid I. Adaptation and validation of the Spanish version of the Nasal Obstruction Symptom Evaluation (NOSE) Scale. Rhinology. 2015:53:176-80.

36. Valero A, Mullol J, Herdman M, Rosales MJ. Measuring outcomes in allergic rhinitis: psychometric characteristics of a Spanish version of the congestion quantifier seven-item test (CQ7). Health Qual Life Outcomes. 2011;9:14.

37. Kacha S, Guillemin F, Jankowski R. Development and validity of the DyNaChron questionnaire for chronic nasal dysfunction. Eur Arch Oto-Rhino-Laryngology. 2012;269:143-53.

38. Fabra JM. Rinomanometria anterior activa (Tesis Doctoral). Barcelona: Universidad Autónoma de Barcelona, Facultad de Medicina (Hospital de la Santa Creu i Sant Pau), 1990.

39. Clement PAR, Gordts F, Standardisation Committee on Objective Assessment of the Nasal Airway, IRS, and ERS. Consensus report on acoustic rhinometry and rhinomanometry. Rhinology. 2005;43:169-79.

40. Hilberg O, Pedersen OF. Acoustic rhinometry: recommendations for technical specifications and standard operating procedures. Rhinol Suppl. 2000;16:3-17.

41. Eccles R. A guide to practical aspects of measurement of human nasal airflow by rhinomanometry. Rhinology. 2011:49:2-10.

42. Demirbas $D$, Cingi C, Çakli H, Kaya E. Use of rhinomanometry in common rhinologic disorders. Expert Rev Med Devices. 2011:8:769-77.

43. Basterra Alegría J, Armengot Carceller M. Exploración clínica y por imagen. Pruebas funcionales en rinología. In: Elsevier, editor. Tratado de otorrinolaringología y patología cervicofacial. 1a edición. Barcelona: MASSON; 2009. p. 289300.

44. Dordal M, Lluch-Bernal M, Sánchez M, Rondón C, Navarro A, Montoro J, et al. Allergen-Specific Nasal Provocation Testing: Review by the Rhinoconjunctivitis Committee of the Spanish Society of Allergy and Clinical Immunology. J Investig Allergol Clin Immunol. 2011;21:1-12.

45. Vogt K, Wernecke K-D, Behrbohm H, GubischW, Argale M. Fourphase rhinomanometry: a multicentric retrospective analysis of 36,563 clinical measurements. Eur Arch Otorhinolaryngol. 2016:273:1185-98.

46. Grymer LF, Hilberg O, Pedersen OF, Rasmussen TR. Acoustic rhinometry: values from adults with subjective normal nasal patency. Rhinology. 1991;29:35-47.

47. Aziz T, Biron VL, Ansari K, Flores-Mir C. Measurement tools for the diagnosis of nasal septal deviation: a systematic review. J Otolaryngol Head Neck Surg. 2014;43:11.

48. Holmstrom M. The use of objective measures in selecting patients for septal surgery. Rhinology. 2010;48:387-93.

49. Matsumoto FY, Gonçalves TRT, Solé D, Wandalsen GF. Specific nasal provocation test with Dermatophagoides pteronyssinus, monitored by acoustic rhinometry, in children with rhinitis. Am J Rhinol Allergy. 2017;31:7-11.

50. Melo AC, de Oliveira de Camargo Gomes A, Santos Cavalcanti A, Justino da Silva $\mathrm{H}$. Acoustic rhinometry in mouth breathing patients: a systematic review. Braz J Otorhinolaryngol. 2015;81:212-8.

51. Orús Dotu C. Rinometría Acústica: Valores de normalidad y correlación rinomanométrica. (Tesis doctoral). Barcelona: Universidad Autónoma de Barcelona, 2003.

52. Straszek SP, Schlünssen V, Sigsgaard T, Pedersen OF. Reference values for acoustic rhinometry in decongested school children and adults: the most sensitive measurement for change in nasal patency. Rhinology. 2007;45:36-9.

53. Zhang G, Solomon P, Rival R, Fenton RS, Cole P. Nasal airway volume and resistance to airflow. Am J Rhinol. 2008;22:3715.

54. Ottaviano G, Fokkens WJ. Measurements of nasal airflow and patency: a critical review with emphasis on the use of peak nasal inspiratory flow in daily practice. Allergy. 2016;71:16274.

55. Kirtsreesakul V, Leelapong J, Ruttanaphol S. Nasal peak inspiratory and expiratory flow measurements for assessing nasal obstruction in allergic rhinitis. Am J Rhinol Allergy. 2014;28:126-30.

56. Teixeira RUF, Zappelini CEM, Alves FS, da Costa EA. Peak nasal inspiratory flow evaluation as an objective method of measuring nasal airflow. Braz J Otorhinolaryngol. 77:47380.

57. Ottaviano G, Scadding GK, Coles S, Lund VJ. Peak nasal inspiratory flow; normal range in adult population. Rhinology. 2006:44:32-5.

58. Chaves C, Ibiapina $C$ da $C$, de Andrade CR, Godinho R, Alvim CG, Cruz ÁA. Correlation between peak nasal inspiratory flow and peak expiratory flow in children and adolescents. Rhinology. 2012; 50:381-5.

59. van Spronsen E, Ebbens FA, Fokkens WJ. Normal peak nasal inspiratory flow rate values in healthy children aged 6 to 11 years in the Netherlands. Rhinology. 2012;50:22-5.

60. Papachristou A, Bourli E, Aivazi D, Futzila E, Papastavrou T, Konstandinidis T, et al. Normal peak nasal inspiratory flow rate values in Greek children and adolescents. Hippokratia. 2008;12:94-7.

61. da Cunha Ibiapina C, Ribeiro de Andrade C, Moreira Camargos PA, Goncalves Alvim C, Augusto Cruz A. Reference values for peak nasal inspiratory flow in children and adolescents in Brazil. Rhinology. 2011;49:304-8.

62. Bouzgarou MD, Saad H, Chouchane A, Cheikh I, Zbidi A, Dessanges J, et al. North African reference equation for peak nasal inspiratory flow. J Laryngol Otol. 2011;125:595-602.

63. Starling-Schwanz R, Peake HL, Salome CM, Toelle BG, Ng KW, Marks $G B$, et al. Repeatability of peak nasal inspiratory flow measurements and utility for assessing the severity of rhinitis. Allergy. 2005;60:795-800.

64. Bermüller C, Kirsche $H$, Rettinger $G$, Riechelmann $H$. Diagnostic Accuracy of Peak Nasal Inspiratory Flow and Rhinomanometry in Functional Rhinosurgery. Laryngoscope. 2008;118:605-10.

65. Fokkens WJ. Objective measurements of nasal function: necessary before nasal surgery? Rhinol J. 2014;52:289-91. 
66. Chaves C, de Andrade CR, Ibiapina C. Objective measures for functional diagnostic of the upper airways: practical aspects. Rhinology. 2014;52:99-103.

67. Ottaviano G, Lund VJ, Coles S, Staffieri A, Scadding GK. Does peak nasal inspiratory flow relate to peak expiratory flow? Rhinology. 2008;46:200-3.

68. Proimos EK, Kiagiadaki DE, Chimona TS, Seferlis FG, Maroudias NJ, Papadakis CE. Comparison of acoustic rhinometry and nasal inspiratory peak flow as objective tools for nasal obstruction assessment in patients with chronic rhinosinusitis. Rhinology. 2015;53:66-74.

69. Klossek J, Lebreton JP, Delagranda A, Dufour X. PNIF measurement in a healthy French population. A prospective study about 234 patients. Rhinol J. 2009;47:389-92.

70. Whitcroft KL, Andrews PJ, Randhawa PS. Peak nasal inspiratory flow correlates with quality of life in functional endoscopic sinus surgery. Clin Otolaryngol. 2017;42:1187-92.

71. Takhar AS, Stephens J, Randhawa PS, Poirrier AL, Andrews $P$. Validation of the sino-nasal outcome test-23 in septorhinoplasty surgery. Rhinology. 2014;52:320-6.

72. Menger DJ, Swart KMA, Nolst Trenité GJ, Georgalas C, Grolman W. Surgery of the external nasal valve: the correlation between subjective and objective measurements. Clin Otolaryngol. 2014;39:150-5

73. Andrews PJ, Choudhury N, Takhar A, Poirrier AL, Jacques $T$, Randhawa PS. The need for an objective measure in septorhinoplasty surgery: are we any closer to finding an answer? Clin Otolaryngol. 2015;40:698-703.

74. Kjaergaard T, Cvancarova M, Steinsvåg SK. Nasal congestion index: A measure for nasal obstruction. Laryngoscope. 2009;119:1628-32

75. Ottaviano G, Lund VJ, Nardello E, Scarpa B, Frasson G, Staffieri $A$, et al. Comparison between unilateral PNIF and rhinomanometry in healthy and obstructed noses. Rhinology. 2014; $52: 25-30$.

76. Ellis AK, Soliman M, Steacy L, Boulay MĖ, Boulet LP, Keith PK, et al. The Allergic Rhinitis - Clinical Investigator Collaborative (AR-CIC): nasal allergen challenge protocol optimization for studying AR pathophysiology and evaluating novel therapies. Allergy Asthma Clin Immunol. 2015;11:16.

77. Niżankowska-Mogilnicka E, Bochenek G, Mastalerz L, Świerczyńska M, Picado C, Scadding G, et al. EAACI/GA2LEN guideline: aspirin provocation tests for diagnosis of aspirin hypersensitivity. Allergy. 2007;62:1111-8.

78. Cuddihy PJ, Eccles R. The use of nasal spirometry for the assessment of unilateral nasal obstruction associated with changes in posture in healthy subjects and subjects with upper respiratory tract infection. Clin Otolaryngol Allied Sci. 2003;28:108-11.

79. Bakker NH, Lohuis PJ, Menger DJ, Trenite GJN, Fokkens WJ, Grimbergen CA. Objective Computerized Determination of the Minimum Cross-Sectional Area of the Nasal Passage on Computed Tomography. Laryngoscope. 2005;115:1809-12.

80. Wakayama T, Suzuki M, Tanuma T, Sutherland K, Rosengarten G, Sampson D. Effect of Nasal Obstruction on Continuous Positive Airway Pressure Treatment: Computational Fluid Dynamics Analyses. PLoS One. 2016;11:e0150951.

81. Lara-Sánchez H, Álvarez Nuño C, Gil-Carcedo Sañudo E, Mayo Iscar A, Vallejo Valdezate LÁ. Evaluación de la obstrucción nasal mediante rinomanometría y escalas subjetivas y medición del éxito terapéutico médico y quirúrgico. Acta Otorrinolaringológica Española. 2017;68:145-50.

82. Hox V, Bobic S, Callebaux I, Jorissen M, Hellings PW. Nasal obstruction and smell impairment in nasal polyp disease: correlation between objective and subjective parameters. Rhinology. 2010;48:426-32.

83. Lam DJ, James KT, Weaver EM. Comparison of anatomic, physiological, and subjective measures of the nasal airway. Am J Rhinol. 2006;20:463-70.

84. Mendes Al, Wandalsen GF, Solé D. Objective and subjective assessments of nasal obstruction in children and adolescents with allergic rhinitis. J Pediatr (Rio J). 2012;88:389-95.

85. Mozzanica F, Gera R, Bulgheroni C, Ambrogi F, Schindler A, Ottaviani F. Correlation between Objective and Subjective Assessment of Nasal Patency. Iran J Otorhinolaryngol. 2016:28:313-9.

86. Valero A, Alonso J, Antépara I, Baró E, Colás C, del Cuvillo A, et al. Health-related quality of life in allergic rhinitis: comparing the short form ESPRINT-15 and MiniRQLQ questionnaires. Allergy. 2007;62:1372-8.

87. Bousquet PJ, Demoly P, Devillier P, Mesbah K, Bousquet J. Impact of allergic rhinitis symptoms on quality of life in primary care. Int Arch Allergy Immunol. 2013;160:393-400.

88. Rudmik L, Hopkins C, Peters A, Smith TL, Schlosser RJ, Soler ZM. Patient-reported outcome measures for adult chronic rhinosinusitis: A systematic review and quality assessment. J Allergy Clin Immunol. 2015;136:1532-1540.e2.

89. Erskine S, Hopkins C, Kumar N, Wilson J, Clark A, Robertson A, et al. A cross sectional analysis of a case-control study about quality of life in CRS in the UK; a comparison between CRS subtypes. Rhinology. 2016;54:311-5.

90. Dávila I, Rondón C, Navarro A, Antón E, Colás C, Dordal MT, et al. Aeroallergen sensitization influences quality of life and comorbidities in patients with nasal polyposis. Am J Rhinol Allergy. 2012;26:e126-31.

91. Alobid I, Bernal-Sprekelsen M, Mullol J. Chronic rhinosinusitis and nasal polyps: the role of generic and specific questionnaires on assessing its impact on patient's quality of life. Allergy. 2008:63:1267-79.

92. Fuller JC, Levesque PA, Lindsay RW. Assessment of the EuroQol 5-Dimension Questionnaire for Detection of Clinically Significant Global Health-Related Quality-of-Life Improvement Following Functional Septorhinoplasty. JAMA Facial Plast Surg. 2017; 19:95-100.

93. Floyd EM, Ho S, Patel P, Rosenfeld RM, Gordin E. Systematic Review and Meta-analysis of Studies Evaluating Functional Rhinoplasty Outcomes with the NOSE Score. Otolaryngol Head Neck Surg. 2017;156:809-15.

94. Devillier P, Bousquet PJ, Grassin-Delyle S, Salvator H, Demoly P, Bousquet J, et al. Comparison of outcome measures in allergic rhinitis in children, adolescents and adults. Pediatr Allergy Immunol. 2016;27:375-81.

95. Meltzer EO. Allergic Rhinitis: Burden of Illness, Quality of Life, Comorbidities, and Control. Immunol Allergy Clin North Am. 2016;36:235-48.

96. González-Núñez V, Valero AL, Mullol J. Impact of sleep as a specific marker of quality of life in allergic rhinitis. Curr Allergy Asthma Rep. 2013;13:131-41. 
97. Lunn M, Craig T. Rhinitis and sleep. Sleep Med Rev. 2011;15:293-9.

98. Colás C, Galera H, Añibarro B, Soler R, Navarro A, Jáuregui I, et al. Disease severity impairs sleep quality in allergic rhinitis (The SOMNIAAR study). Clin Exp Allergy. 2012;42:1080-7.

99. Thomas AJ, Orlandi RR, Ashby S, Mace JC, Smith TL, Alt JA. Nasal obstruction has a limited impact on sleep quality and quality of life in patients with chronic rhinosinusitis. Laryngoscope. 2016;126:1971-6.

100. Meltzer EO, Munafo DA, Chung W, Gopalan G, Varghese ST. Intranasal mometasone furoate therapy for allergic rhinitis symptoms and rhinitis-disturbed sleep. Ann Allergy Asthma Immunol. 2010;105:65-74.

101. Hoehle LP, Phillips KM, Bergmark RW, Caradonna DS, Gray ST, Sedaghat AR. Symptoms of chronic rhinosinusitis differentially impact general health-related quality of life. Rhinology. 2016;54:316-22.

102. Alt JA, DeConde AS, Mace JC, Steele TO, Orlandi RR, Smith TL. Quality of Life in Patients With Chronic Rhinosinusitis and Sleep Dysfunction Undergoing Endoscopic Sinus Surgery. JAMA Otolaryngol Neck Surg. 2015;141:1.

103. Alt JA, Smith TL, Mace JC, Soler ZM. Sleep quality and disease severity in patients with chronic rhinosinusitis. Laryngoscope. 2013;123:2364-70.

104. Badia X, Roset M, Montserrat S, Herdman M, Segura A. [The Spanish version of EuroQol: a description and its applications. European Quality of Life scale]. Med Clin (Barc). 1999;7985.

105. Alonso J, Prieto L, Antó JM. [The Spanish version of the SF-36 Health Survey (the SF-36 health questionnaire): an instrument for measuring clinical results]. Med Clin (Barc). 1995; 104:771-6.

106. Toledano A, Herráiz C, García E, Navas C, Aparicio JM, García Simal $M$, et al. [The use of Quality of Life Questionnaire in patients with nasal polyposis]. Acta Otorrinolaringol Esp. 2006; 57:401-4.

107. Alobid I, Enseñat J, Mariño-Sánchez F, Rioja E, de Notaris M, Mullol J, et al. Expanded endonasal approach using vascularized septal flap reconstruction for skull base tumors has a negative impact on sinonasal symptoms and quality of life. Am J Rhinol Allergy. 2013;27:426-31.

108. de los Santos G, Reyes P, del Castillo R, Fragola C, Royuela A. Cross-cultural adaptation and validation of the sino-nasal outcome test (SNOT-22) for Spanish-speaking patients. Eur Arch Otorhinolaryngol. 2015;272:3335-40.

109. Soler $R$, de la Hoz B, Badia X, Mercadal J, Lozano R, Benavides $A$, et al. [Validation of the Spanish version of the Rhinoconjunctivitis Quality of Life Questionnaire (RQLQ)]. Rev Clin Esp. 2004;204:131-8.

110. Baiardini I, Pasquali M, Giardini A, Specchia C, Passalacqua G, Venturi S, et al. Rhinasthma: a new specific QOL questionnaire for patients with rhinitis and asthma. Allergy. 2003;58:28994.

111. Simopoulos E, Katotomichelakis M, Gouveris H, Tripsianis G, Livaditis M, Danielides V. Olfaction-associated quality of life in chronic rhinosinusitis: adaptation and validation of an olfactionspecific questionnaire. Laryngoscope. 2012;122:1450-4.

112. Royuela Rico A, Macías Fernández J. Propiedades Clinimétricas De La Versión Castellana Del Cuestionario De Pittsburg. Vigilia-Sueño. 1997;9:81-94.
113. Valero A, Alonso J, Antepara I, Baró E, Colas C, del Cuvillo A, et al. Development and Validation of a New Spanish Instrument to Measure Health-Related Quality of Life in Patients with Allergic Rhinitis: The ESPRINT Questionnaire. Value Heal. 2007; 10:466-77.

114. Valero A, Izquierdo I, Sastre J, Navarro AM, Baró E, MartíGuadaño E, et al. ESPRINT-15 questionnaire (Spanish version): reference values according to disease severity using both the original and the modified ARIA classifications. J Investig Allergol Clin Immunol. 2013;23:14-9.

115. Tarasidis GS, DeConde AS, Mace JC, Ashby S, Smith TL, Orlandi RR, et al. Cognitive dysfunction associated with pain and quality of life in chronic rhinosinusitis. Int Forum Allergy Rhinol. 2015;5:1004-9.

116. Linneberg A, Dam Petersen K, Hahn-Pedersen J, Hammerby E, Serup-Hansen N, Boxall N. Burden of allergic respiratory disease: a systematic review. Clin Mol Allergy. 2016;14:12.

117. de la Hoz Caballer B, Rodríguez M, Fraj J, Cerecedo I, AntolínAmérigo $D$, Colás $C$. Allergic rhinitis and its impact on work productivity in primary care practice and a comparison with other common diseases: the Cross-sectional study to evAluate work Productivity in allergic Rhinitis compared with other common dlseases (CAPRI) study. Am J Rhinol Allergy. 2012;26:390-4.

118. Colás C, Brosa M, Antón E, Montoro J, Navarro A, Dordal $M T$, et al. Estimate of the total costs of allergic rhinitis in specialized care based on real-world data: the FERIN Study. Allergy. 2017;72:959-66.

119. Wang R, Souza NF, Fortes JA, Santos GJ, Faria Neto JR, Zytinski L. Apical ballooning syndrome secondary to nasal decongestant abuse. Arq Bras Cardiol. 2009;93:e75-8.

120. Greiwe JC, Bernstein JA. Combination therapy in allergic rhinitis: What works and what does not work. Am J Rhinol Allergy. 2016;30:391-6.

121. Serveaux M, Burnier M, Pruijm M. [Drugs: an underestimated cause of arterial hypertension]. Rev Med Suisse. 2014;10:16612, 1664-5.

122. Deckx L, De Sutter Al, Guo L, Mir NA, van Driel ML. Nasal decongestants in monotherapy for the common cold. Cochrane Database Syst Rev. 2016;CD009612.

123. Gonzalez-Estrada A, Geraci SA. Allergy Medications During Pregnancy. Am J Med Sci. 2016;352:326-31.

124. Brożek JL, Bousquet J, Baena-Cagnani CE, Bonini S, Canonica GW, Casale TB, et al. Allergic Rhinitis and its Impact on Asthma (ARIA) guidelines: 2010 Revision. J Allergy Clin Immunol. 2010;126:466-76.

125. Taverner D, Latte GJ. Nasal decongestants for the common cold. Cochrane Database Syst Rev. 2007;CD001953.

126. Kollar C, Schneider H, Waksman J, Krusinska E. Meta-analysis of the efficacy of a single dose of phenylephrine $10 \mathrm{mg}$ compared with placebo in adults with acute nasal congestion due to the common cold. Clin Ther. 2007;29:1057-70.

127. Orlandi RR, Kingdom TT, Hwang PH, Smith TL, Alt JA, Baroody FM, et al. International Consensus Statement on Allergy and Rhinology: Rhinosinusitis. 2016;6:S22-209.

128. Valero A, Sarandeses A. Documento de Consenso sobre Poliposis Nasal SEAIC-SEORL PROYECTO POLINA. J Investig Allergol Clin Immunol. 2011;21:1-58. 
129. Bousquet J, Khaltaev N, Cruz AA, Denburg J, Fokkens WJ, Togias A, et al. Allergic Rhinitis and its Impact on Asthma (ARIA) 2008. Allergy. 2008;63:8-160.

130. Fokkens WJ, Lund VJ, Mullol J, Bachert C, Alobid I, Baroody F, et al. EPOS 2012: European position paper on rhinosinusitis and nasal polyps 2012. A summary for otorhinolaryngologists. Rhinology. 2012;50:1-12.

131. Seidman MD, Gurgel RK, Lin SY, Schwartz SR, Baroody FM, Bonner JR, et al. Clinical Practice Guideline: allergic rhinitis executive summary. Otolaryngol Neck Surg. 2015;152:197206.

132. Mullol J, Obando A, Pujols L, Alobid I. Corticosteroid Treatment in Chronic Rhinosinusitis: The Possibilities and the Limits. Immunol Allergy Clin North Am. 2009;29:657-68.

133. Hayward G, Thompson MJ, Perera R, Del Mar CB, Glasziou PP, Heneghan CJ. Corticosteroids for the common cold. Cochrane Database Syst Rev. 2012;CD008116.

134. Seidman MD, Gurgel RK, Lin SY, Schwartz SR, Baroody FM, Bonner JR, et al. Clinical Practice Guideline: Allergic Rhinitis. Otolaryngol Head Neck Surg. 2015;152:S1-43.

135. Hellings PW, Klimek L, Cingi C, Agache I, Akdis C, Bachert C, et al. Non-Allergic Rhinitis: Position paper of the European Academy of Allergology and Clinical Immunology. Allergy. 2017;72:1657-65.

136. Joe SA, Thambi R, Huang J. A systematic review of the use of intranasal steroids in the treatment of chronic rhinosinusitis. Otolaryngol Neck Surg. 2008;139:340-7.

137. Chong LY, Head K, Hopkins C, Philpott C, Schilder AG, Burton MJ. Intranasal steroids versus placebo or no intervention for chronic rhinosinusitis. Cochrane Database Syst Rev. 2016; CD011996.

138. Stjärne P, Olsson P, Ålenius M. Use of Mometasone Furoate to Prevent Polyp Relapse After Endoscopic Sinus Surgery. Arch Otolaryngol Neck Surg. 2009;135:296-302.

139. Van Zele T, Gevaert P, Holtappels G, Beule A, Wormald PJ, Mayr S, et al. Oral steroids and doxycycline: Two different approaches to treat nasal polyps. J Allergy Clin Immunol. 2010;125:1069-76.e4.

140. Head K, Chong LY, Hopkins C, Philpott C, Burton MJ, Schilder AG. Short-course oral steroids alone for chronic rhinosinusitis. Cochrane Database Syst Rev. 2016;CD011991.

141. Scadding GK, Durham SR, Mirakian R, Jones NS, Drake-Lee $A B$, Ryan $D$, et al. $B S A C l$ guidelines for the management of rhinosinusitis and nasal polyposis. Clin Exp Allergy. 2007;38:260-75.

142. Mösges R, König V, Köberlein J. The Effectiveness of Modern Antihistamines for Treatment of Allergic Rhinitis - An IPD MetaAnalysis of 140,853 Patients. Allergol Int. 2013;62:215-22.

143. Simons FE, Simons KJ. Histamine and H1-antihistamines: Celebrating a century of progress. J Allergy Clin Immunol. 2011;128:1139-50.e4.

144. Juel-Berg N, Darling P, Bolvig J, Foss-Skiftesvik MH, Halken $S$, Winther $L$, et al. Intranasal corticosteroids compared with oral antihistamines in allergic rhinitis: A systematic review and meta-analysis. Am J Rhinol Allergy. 2017;31:19-28.

145. De Sutter Al, Saraswat A, van Driel ML. Antihistamines for the common cold. Cochrane Database Syst Rev. 2015;CD001267.

146. Roca-Ferrer, L Pujols, M Pérez-González, I Alobid, A Valero, C Picado, R Murray JM. MP29-02 reduces both eosinophil survival and proinflammatory cytokines secretion from nasal epithelial cells in an in vitro model of human nasal eosinophilic inflamation. [Abstract P09]. Allergy. 2015;70:4-5.

147. Pujols L, Roca-Ferrer J, Callejas B, Fuentes-Prado M, PérezGonzález, Alobid I, Valero A, Picado C, Murray R, Mullol J. Pujols L, Roca-Ferrer J, Callejas B, Fuentes-Prado M, Pérez-González, Alobid I, Valero A, Picado C, Murray R, Mullol J. Mp-azeflu has superior effect on the transactivation of anti-inflammatory genes than fluticasone propionate and azelastine alone in nasal mucosa and polyp fibroblasts. [Abstract P1181]. Allergy. 2017;72:654.

148. Brożek JL, Bousquet J, Agache I, Agarwal A, Bachert C, BosnicAnticevich S, et al. Allergic Rhinitis and its Impact on Asthma (ARIA) guidelines-2016 revision. J Allergy Clin Immunol. 2017; 140:950-8.

149. Carr W, Bernstein J, Lieberman P, Meltzer E, Bachert C, Price D, et al. A novel intranasal therapy of azelastine with fluticasone for the treatment of allergic rhinitis. J Allergy Clin Immunol. 2012;129:1282-9.e10.

150. Bousquet J, Schünemann HJ, Hellings PW, Arnavielhe $S$, Bachert C, Bedbrook A, et al. MACVIA clinical decision algorithm in adolescents and adults with allergic rhinitis. J Allergy Clin Immunol. 2016;138:367-374.e2.

151. Rodrigo GJ, Yañez $A$. The role of antileukotriene therapy in seasonal allergic rhinitis: a systematic review of randomized trials. Ann Allergy, Asthma Immunol. 2006;96:779-86.

152. Wei $\mathrm{C}$. The efficacy and safety of $\mathrm{H1}$-antihistamine versus Montelukast for allergic rhinitis: A systematic review and meta-analysis. Biomed Pharmacother. 2016;83:989-97.

153. Xu Y, Zhang J, Wang J. The efficacy and safety of selective $\mathrm{H} 1$-antihistamine versus leukotriene receptor antagonist for seasonal allergic rhinitis: a meta-analysis. PLoS One. 2014;9:e112815.

154. Wentzel JL, Soler ZM, DeYoung K, Nguyen SA, Lohia S, Schlosser RJ. Leukotriene antagonists in nasal polyposis: a meta-analysis and systematic review. Am J Rhinol Allergy. 2013;27:482-9.

155. AlBalawi ZH, Othman SS, AlFaleh K. Intranasal ipratropium bromide for the common cold. Cochrane Database Syst Rev. 2011;CD008231.

156. Van Gerven L, Steelant B, Alpizar YA, Talavera K, Hellings PW. Therapeutic effect of capsaicin nasal treatment in patients with mixed rhinitis unresponsive to intranasal steroids. Allergy. 2018;73:248-50.

157. Gevorgyan A, Segboer C, Gorissen R, van Drunen CM, Fokkens W. Capsaicin for non-allergic rhinitis. Fokkens W, editor. Cochrane Database Syst Rev. 2015;CD010591.

158. Xu JJ, Sowerby L, Rotenberg BW. Aspirin desensitization for aspirin-exacerbated respiratory disease (Samter's Triad): a systematic review of the literature. Int Forum Allergy Rhinol. 2013;3:915-20.

159. King D, Mitchell B, Williams C, Spurling G. Saline nasal irrigation for acute upper respiratory tract infections. Cochrane Database Syst Rev. 2015;CD006821.

160. Lin L, Chen Z, Cao Y, Sun G. Normal saline solution nasalpharyngeal irrigation improves chronic cough associated with allergic rhinitis. Am J Rhinol Allergy. 2017;31:96-104.

161. Chong LY, Head K, Hopkins C, Philpott C, Glew S, Scadding $\mathrm{G}$, et al. Saline irrigation for chronic rhinosinusitis. Cochrane Database Syst Rev. 2016;CD011995. 
162. Rudmik L, Soler ZM. Medical Therapies for Adult Chronic Sinusitis. JAMA. 2015;314:926-39.

163. Pfaar O, Mullol J, Anders C, Hörmann K, Klimek L. Cyclamen europaeum nasal spray, a novel phytotherapeutic product for the management of acute rhinosinusitis: a randomized double-blind, placebo-controlled trial. Rhinology. 2012;50: 37-44.

164. Portnoy J, Kennedy K, Sublett J, Phipatanakul W, Matsui E, Barnes $C$, et al. Environmental assessment and exposure control: a practice parameter--furry animals. Ann Allergy Asthma Immunol. 2012;108:223.e1-15.

165. Nurmatov U, van Schayck CP, Hurwitz B, Sheikh A. House dust mite avoidance measures for perennial allergic rhinitis: an updated Cochrane systematic review. Allergy. 2012;67:15865.

166. Cox L, Nelson H, Lockey R, Calabria C, Chacko T, Finegold I, et al. Allergen immunotherapy: A practice parameter third update. J Allergy Clin Immunol. 2011;127:S1-55.

167. Cardona V, Luengo O, Labrador-Horrillo M. Immunotherapy in allergic rhinitis and lower airway outcomes. Allergy. 2017:72:35-42.

168. Erekosima N, Suarez-Cuervo C, Ramanathan M, Kim JM, Chelladurai $Y$, Segal JB, et al. Effectiveness of subcutaneous immunotherapy for allergic rhinoconjunctivitis and asthma: A Systematic Review. Laryngoscope. 2014;124:616-27.

169. Lin SY, Erekosima N, Kim JM, Ramanathan M, Suarez-Cuervo C, Chelladurai $Y$, et al. Sublingual Immunotherapy for the Treatment of Allergic Rhinoconjunctivitis and Asthma. JAMA. 2013:309:1278-88.

170. Feng B, Xiang H, Jin H, Gao J, Huang S, Shi Y, et al. Efficacy of Sublingual Immunotherapy for House Dust Mite-Induced Allergic Rhinitis: A Meta-Analysis of Randomized Controlled Trials. Allergy Asthma Immunol Res. 2017;9:220-8.

171. Durham SR, Penagos M. Sublingual or subcutaneous immunotherapy for allergic rhinitis? J Allergy Clin Immunol. 2016:137:339-49.e10.

172. Calderon MA, Alves B, Jacobson M, Hurwitz B, Sheikh $A$, Durham S. Allergen injection immunotherapy for seasonal allergic rhinitis. Cochrane Database Syst Rev. 2007;CD001936.

173. Radulovic S, Wilson D, Calderon M, Durham S. Systematic reviews of sublingual immunotherapy (SLIT). Allergy. 2011;66:740-52.

174. Di Bona D, Plaia A, Leto-Barone MS, La Piana S, Di Lorenzo G. Efficacy of Grass Pollen Allergen Sublingual Immunotherapy Tablets for Seasonal Allergic Rhinoconjunctivitis. JAMA Intern Med. 2015;175:1301-9.

175. Serrano E, Wahn HU, Didier A, Bachert C. 300IR 5-Grass pollen sublingual tablet offers relief from nasal symptoms in patients with allergic rhinitis. Am J Rhinol Allergy. 2014;28:471-6.

176. Mosbech H, Canonica GW, Backer V, de Blay F, Klimek L, Broge $L$, et al. SQ house dust mite sublingually administered immunotherapy tablet (ALK) improves allergic rhinitis in patients with house dust mite allergic asthma and rhinitis symptoms. Ann Allergy Asthma Immunol. 2015;114:13440.

177. Rondón C, Campo P, Salas M, Aranda A, Molina A, González M, et al. Efficacy and safety of $D$. pteronyssinus immunotherapy in local allergic rhinitis: a double-blind placebo-controlled clinical trial. Allergy. 2016;71:1057-61.
178. DeYoung K, Wentzel JL, Schlosser RJ, Nguyen SA, Soler ZM. Systematic review of immunotherapy for chronic rhinosinusitis. Am J Rhinol Allergy. 2014;28:145-50.

179. Tsabouri S, Tseretopoulou X, Priftis K, Ntzani EE. Omalizumab for the Treatment of Inadequately Controlled Allergic Rhinitis: A Systematic Review and Meta-Analysis of Randomized Clinical Trials. J Allergy Clin Immunol Pract. 2014;2:332-340.e1.

180. Gevaert P, Calus L, Van Zele T, Blomme K, De Ruyck N, Bauters $W$, et al. Omalizumab is effective in allergic and nonallergic patients with nasal polyps and asthma. J Allergy Clin Immunol. 2013;131:110-6.e1.

181. Bachert C, Mannent L, Naclerio RM, Mullol J, Ferguson BJ, Gevaert $P$, et al. Effect of Subcutaneous Dupilumab on Nasal Polyp Burden in Patients With Chronic Sinusitis and Nasal Polyposis. JAMA. 2016:315:469-79.

182. Gevaert P, Van Bruaene N, Cattaert T, Van Steen K, Van Zele T, Acke F, et al. Mepolizumab, a humanized anti-IL-5 mAb, as a treatment option for severe nasal polyposis. J Allergy Clin Immunol. 2011;128:989-995.e8.

183. Castro M, Mathur S, Hargreave F, Boulet L-P, Xie F, Young J, et al. Reslizumab for Poorly Controlled, Eosinophilic Asthma. Am J Respir Crit Care Med. 2011;184:1125-32.

184. Weinstein SF, Germinaro M, Bardin P, Korn S, Bateman ED. Efficacy of Reslizumab with Asthma, Chronic Sinusitis with Nasal Polyps and Elevated Blood Eosinophils. J Allergy Clin Immunol. 2016;137:AB86.

185. Pothoven KL, Norton JE, Suh LA, Carter RG, Harris KE, Biyasheva $A$, et al. Neutrophils are a major source of the epithelial barrier disrupting cytokine oncostatin $\mathrm{M}$ in patients with mucosal airways disease. J Allergy Clin Immunol. 2017;139:1966-78. e9.

186. Ceelen WP. Clinical research in surgery: Threats and opportunities. Eur Surg Res. 2014;53:95-107.

187. Hirst A, Agha RA, Rosin D, McCulloch P. How can we improve surgical research and innovation?: The IDEAL framework for action. Int J Surg. 2013;11:1038-42.

188. Di Rienzo Businco L, Di Rienzo Businco A, Lauriello M. Comparative study on the effectiveness of Coblation-assisted turbinoplasty in allergic rhinitis. Rhinology. 2010;48:174-8.

189. Gunhan K, Unlu H, Yuceturk AV, Songu M. Intranasal steroids or radiofrequency turbinoplasty in persistent allergic rhinitis: Effects on quality of life and objective parameters. Eur Arch Oto-Rhino-Laryngology. 2011;268:845-50.

190. Chhabra N, Houser SM. Surgical options for the allergic rhinitis patient. Curr Opin Otolaryngol Head Neck Surg. 2012;20:199204.

191. Sinno S, Mehta K, Lee Z-H, Kidwai S, Saadeh PB, Lee MR. Inferior Turbinate Hypertrophy in Rhinoplasty: Systematic Review of Surgical Techniques. Plast Reconstr Surg. 2016;138:419-29.

192. Batra PS, Seiden AM, Smith TL. Surgical management of adult inferior turbinate hypertrophy: A systematic review of the evidence. Laryngoscope. 2009;119:1819-27.

193. Acevedo JL, Camacho M, Brietzke SE. Radiofrequency Ablation Turbinoplasty versus Microdebrider-Assisted Turbinoplasty: A Systematic Review and Meta-analysis. Otolaryngol Head Neck Surg. 2015;153:951-6.

194. Nease CJ, Krempl GA. Radiofrequency treatment of turbinate hypertrophy: A randomized, blinded, placebo-controlled clinical trial. Otolaryngol Head Neck Surg. 2004;130:291-9. 
195. Civelek Ş, Özçelik M, Emre IE, Çakir BÖ, Turgut S. Comparison of radiofrequency applied to the total inferior choncha with application to its anterior third. Auris Nasus Larynx. 2010;37:589-93.

196. Hytönen ML, Bäck LJJ, Malmivaara A, Roine RP. Radiofrequency thermal ablation for patients with nasal symptoms: a systematic review of effectiveness and complications. Eur Arch Otorhinolaryngol. 2009;266:1257-66.

197. Passali D, Loglisci M, Politi L, Passali GC, Kern E. Managing turbinate hypertrophy: coblation vs. radiofrequency treatment. Eur Arch Oto-Rhino-Laryngology. 2016;273:1449-53.

198. Dhulipalla S. Comparative Study of Response Through Reduction in the Size of Hypertrophied Inferior Turbinate Causing Nasal Obstruction by Different Surgical Modalities: A Prospective Study. Indian J Otolaryngol Head Neck Surg. 2015;67:56-9.

199. Gindros G, Kantas I, Balatsouras DG, Kaidoglou A, Kandiloros D. Comparison of ultrasound turbinate reduction, radiofrequency tissue ablation and submucosal cauterization in inferior turbinate hypertrophy. Eur Arch Oto-Rhino-Laryngology. 2010;267:1727-33

200. Sroka R, Janda P, Killian T, Vaz F, Betz CS, Leunig A. Comparison of long term results after Ho:YAG and diode laser treatment of hyperplastic inferior nasal turbinates. Lasers Surg Med. 2007;39:324-31.

201. Cakli H, Cingi C, Güven E, Gurbuz MK, Kaya E. Diode laser treatment of hypertrophic inferior turbinates and evaluation of the results with acoustic rhinometry. Eur Arch Oto-RhinoLaryngology. 2012;269:2511-7.

202. De Corso E, Bastanza G, Di Donfrancesco V, Guidi ML, Morelli Sbarra G, Passali GC, et al. Riduzione volumetrica dei turbinati inferiori con radiofrequenze: Risultati clinici a lungo termine. Acta Otorhinolaryngol Ital. 2016;36:199-205.

203. Veit JA, Nordmann M, Dietz B, Sommer F, Lindemann J, Rotter $\mathrm{N}$, et al. Three different turbinoplasty techniques combined with septoplasty: Prospective randomized trial. Laryngoscope. 2016;303-8.

204. Garzaro M, Landolfo V, Pezzoli M, Defilippi S, Campisi P, Giordano C, et al. Radiofrequency volume turbinate reduction versus partial turbinectomy: Clinical and histological features. Am J Rhinol Allergy. 2012;26:321-5.

205. Passali D, Passali F, Passali G, Damiani V, Belussi L. Treatmeant of Inferior Turbinate Hypertrophy: A randomized Clinical Trial. Ann Otol Rhinol Laryngol. 2003;112:683-8.

206. Cingi C, Ure B, Cakli H, Ozudogru E. Microdebrider-assisted versus radiofrequency-assisted inferior turbinoplasty: a prospective study with objective and subjective outcome measures. Acta Otorhinolaryngol Ital. 2010;30:138-43.

207. Vijay Kumar K, Kumar S, Garg S. A Comparative Study of Radiofrequency Assisted Versus Microdebrider Assisted Turbinoplasty in Cases of Inferior Turbinate Hypertrophy. Indian J Otolaryngol Head Neck Surg. 2014;66:35-9.

208. Yañez C, Mora N. Inferior turbinate debriding technique: Tenyear results. Otolaryngol Head Neck Surg. 2008;138:170-5.

209. Bakshi SS, Shankar Manoharan K, Gopalakrishnan S. Comparison of the long term efficacy of radiofrequency ablation and surgical turbinoplasty in inferior turbinate hypertrophy: a randomized clinical study. Acta Otolaryngol. 2017;23:1-6.
210. Aksoy F, Yildirim YS, Veyseller B, Ozturan O, Demirhan $H$ Midterm outcomes of outfracture of the inferior turbinate. Otolaryngol Head Neck Surg. 2010;143:579-84.

211. Lee DC, Jin S-G, Kim BY, Yoo S, Han S, Lee YJ, et al. Does the Effect of Inferior Turbinate Outfracture Persist? Plast Reconstr Surg. 2017;139:386e-391e.

212. Luk LJ, Steele TO, Mace JC, Soler ZM, Rudmik L, Smith TL. Health utility outcomes in patients undergoing medical management for chronic rhinosinusitis: a prospective multiinstitutional study. Int Forum Allergy Rhinol. 2015;5:1018-27.

213. Stewart M, Smith TL, Weaver EM, Witsell DL, Yueh B, Hannley MT, et al. Outcomes after nasal septoplasty: Results from the Nasal Obstruction Septoplasty Effectiveness (NOSE) study. Otolaryngol Head Neck Surg. 2004;130:283-90.

214. Smith TL, Litvack JR, Hwang PH, Loehrl TA, Mace JC, Fong KJ, et al. Determinants of outcomes of sinus surgery: A multiinstitutional prospective cohort study. Otolaryngol Head Neck Surg. 2010;142:55-63.

215. Georgalas C, Cornet M, Adriaensen G, Reinartz S, Holland C, Prokopakis E, et al. Evidence-based Surgery for Chronic Rhinosinusitis with and without Nasal Polyps. Curr Allergy Asthma Rep. 2014;14:1-7.

216. Alobid I, Benítez P, Bernal-Sprekelsen M, Roca J, Alonso J, Picado C, et al. Nasal polyposis and its impact on quality of life: comparison between the effects of medical and surgical treatments. Allergy. 2005;60:452-8.

217. Blomqvist E, Bergstedt $H$, Stjarne $P$, Lundblad L. A randomized prospective study comparing medical and medical-surgical treatment of nasal polyposis by CT. Acta Otolaryngol. 2009; 129:545-9.

218. Rimmer J, Fokkens W, Chong LY, Hopkins C. Surgical versus medical interventions for chronic rhinosinusitis with nasal polyps. Cochrane Database Syst Rev. 2014;CD006991.

219. Leung RM, Dinnie K, Smith TL. When do the risks of repeated courses of corticosteroids exceed the risks of surgery? Int Forum Allergy Rhinol. 2014;4:871-6.

220. Rudmik L, Soler ZM, Mace JC, Schlosser RJ, Smith TL. Economic evaluation of endoscopic sinus surgery versus continued medical therapy for refractory chronic rhinosinusitis. Laryngoscope. 2015;125:25-32.

221. Benninger MS, Sindwani R, Holy CE, Hopkins C. Early versus delayed endoscopic sinus surgery in patients with chronic rhinosinusitis: impact on health care utilization. Otolaryngol Head Neck Surg. 2015;152:546-52.

222. Pundir V, Pundir J, Lancaster G, Baer S, Kirkland P, Cornet M, et al. Role of corticosteroids in Functional Endoscopic Sinus Surgery - a systematic review and meta-analysis. Rhinology. 2016:54:3-19.

223. Chen F-H, Deng J, Hong H-Y, Xu R, Guo J-B, Hou W-J, et al. Extensive versus functional endoscopic sinus surgery for chronic rhinosinusitis with nasal polyps and asthma: A 1-year study. Am J Rhinol Allergy. 2016;30:143-8.

224. Sharma R, Lakhani R, Rimmer J, Hopkins C. Surgical interventions for chronic rhinosinusitis with nasal polyps. Cochrane database Syst Rev. 2014;CD006990.

225. Bassiouni A, Wormald PJ. Role of frontal sinus surgery in nasal polyp recurrence. Laryngoscope. 2013;123:36-41.

226. Fandiño M, Macdonald KI, Lee J, Witterick IJ. The use of postoperative topical corticosteroids in chronic rhinosinusitis 
with nasal polyps: A systematic review and meta-analysis. Am J Rhinol Allergy. 2013;27:146-57.

227. van der Veen J, Seys SF, Timmermans $M$, Levie P, Jorissen M, Fokkens WJ, et al. Real-life study showing uncontrolled rhinosinusitis after sinus surgery in a tertiary referral centre. Allergy Eur J Allergy Clin Immunol. 2016;72:282-90.

228. Vashishta R, Soler ZM, Nguyen S, Schlosser RJ. A systematic review and meta-analysis of asthma outcomes following endoscopic sinus surgery for chronic rhinosinusitis. Int Forum Allergy Rhinol. 2013;3:788-94.

229. Rix I, Hakansson K, Larsen CG, Frendo M, von Buchwald C. Management of chronic rhinosinusitis with nasal polyps and coexisting asthma: A systematic review. J Rhinol. 2015;29:193201.

230. Awad OG, Fasano MB, Lee JH, Graham SM. Asthma outcomes after endoscopic sinus surgery in aspirin-tolerant versus aspirin-induced asthmatic patients. Am J Rhinol. 2008;22:197203.

231. Rosbe KW, Jones DT, Rahbar R, Lahiri T, Auerbach AD. Endoscopic sinus surgery in cystic fibrosis: do patients benefit from surgery? Int J Pediatr Otorhinolaryngol. 2001;61:113-9.

232. Kempainen RR, Sajan J, Pylkas AM, Dunitz JM, Rimell FL, Milla CE. Effect of endoscopic sinus surgery on pulmonary status of adults with cystic fibrosis. Otolaryngol Head Neck Surg. 2012;147:557-62.

233. Ayoub N, Thamboo A, Habib A-R, Nayak J V, Hwang PH. Determinants and outcomes of upfront surgery versus medical therapy for chronic rhinosinusitis in cystic fibrosis. Int Forum Allergy Rhinol. 2017;7:450-8.

234. Smith TL, Kern R, Palmer JN, Schlosser R, Chandra RK, Chiu $A G$, et al. Medical therapy vs surgery for chronic rhinosinusitis: a prospective, multi-institutional study with 1-year follow-up. Int Forum Allergy Rhinol. 2013;3:4-9.

235. Goudakos J, Fishman J, Patel K. A systematic review of the surgical techniques for the treatment of internal nasal valve collapse : where do we stand ? Clin Otolaryngol. 2017;42:6070.

236. Spielmann PM, White PS, Hussain SS. Surgical techniques for the treatment of nasal valve collapse: a systematic review. Laryngoscope. 2009;119:1281-90.

237. Chambers K. Evaluation of Improvement in Nasal Obstruction Following Nasal Valve Correction in Patients With a History of Failed Septoplasty. JAMA Facial Plast Surg. 2015;17:347-50.

238. Erickson B, Hurowitz R, Jeffery C, Ansari K, El Hakim H, Wright $E D$, et al. Acoustic rhinometry and video endoscopic scoring to evaluate postoperative outcomes in endonasal spreader graft surgery with septoplasty and turbinoplasty for nasal valve collapse. J Otolaryngol - Head Neck Surg. 2016;45:2-7.

239. Barham HP, Knisely A, Christensen J, Sacks R, Marcells GN, Harvey RJ. Costal Cartilage Lateral Crural Strut Graft vs Cephalic Crural Turn-in for Correction of External Valve Dysfunction. JAMA Facial Plast Surg. 2017;17:340-5.

240. Gassner HG, Maneschi P, Haubner F. The Stairstep Graft. JAMA Facial Plast Surg. 2014;16:440-3.

241. Timmer FCA, Roth JA, Börjesson PKE, Lohuis PJFM. The lateral crural underlay spring graft. Facial Plast Surg. 2013;29:140-5.

242. Craig J, Goyal P, Suryadevara A. Upper lateral strut graft: A technique to improve the internal nasal valve. Am J Rhinol Allergy. 2014;28:65-9.
243. Sahin MS, Ozmen OA. Early Results and Description of a New Modification of Spreader Graft to Enlarge Nasal Valve Area. J Craniofac Surg. 2016;27:839-42.

244. Jalali MM. Comparison of effects of spreader grafts and flaring sutures on nasal airway resistance in rhinoplasty. Eur Arch Oto-Rhino-Laryngology. 2015;272:2299-303.

245. Nuara MJ, Mobley SR. Nasal valve suspension revisited. Laryngoscope. 2007;117:2100-6.

246. André RF, Vuyk HD. Nasal valve surgery; our experience with the valve suspension technique. Rhinology. 2008;46:66-9.

247. Rizvi SS, Gauthier MG. Lateralizing the collapsed nasal valves simplified: 10-Year survey of a simple concealed suture technique. Laryngoscope. 2011;121:558-61.

248. Manickavasagam J, lqbal I, Wong S, Raghavan U. Alar suspension sutures in the management of nasal valve collapse. Ann Otol Rhinol Laryngol. 2015;124:740-4.

249. San Nicoló $M$, Stelter $K$, Sadick $H$, Bas M, Berghaus $A$. Absorbable Implant to Treat Nasal Valve Collapse. Facial Plast Surg. 2017;33:233-40.

250. Ramakrishnan JB, Danner CJ, Yee SW. The use of porous polyethylene implants to correct nasal valve collapse. Otolaryngol Head Neck Surg. 2007;136:357-61.

251. Bertossi D, Walter C, Nocini PF. The Pull-up Spreader High (PUSH) Technique for Nasal Tip Support. Aesthetic Surg J. 2014;34:1153-61.

252. Kemaloglu CA, Altiparmak M. The alar rim flap: A novel technique to manage malpositioned lateral crura. Aesthetic Surg J. 2015;35:920-6.

253. Bared A, Rashan A, Caughlin BP, Toriumi DM. Lower Lateral Cartilage Repositioning. JAMA Facial Plast Surg. 2014;16:2617.

254. Weissman J, Most S. Radiofrequency Thermotherapy vs BoneAnchored Suspension for Treatment of Lateral Nasal Wall Insufficiency: A Randomized Clinical Trial. JAMA Facial Plast Surg. 2015;17:84-9.

255. Bessler S, Kim Haemmig H, Schuknecht B, Meuli-Simmen C, Strub B. Anterior spreader flap technique: A new minimally invasive method for stabilising and widening the nasal valve. J Plast Reconstr Aesthetic Surg. 2015;68:1687-93.

256. Saban $Y$, Javier DB, Massa M. Nasal lift-nasal valve lift and nasal tip lift-preliminary results of a new technique using noninvasive self-retaining unidirectional nasal suspension with threads. Facial Plast Surg. 2014;30:661-9.

257. Cedin AC, Atallah ÁN, Andriolo RB, Cruz OL, Pignatari SN. Surgery for congenital choanal atresia. Cochrane Database Syst Rev. 2012;CD008993.

258. Strychowsky JE, Kawai K, Moritz E, Rahbar R, Adil EA. To stent or not to stent? A meta-analysis of endonasal congenital bilateral choanal atresia repair. Laryngoscope. 2016;126:21827.

259. Eladl HM, Khafagy YW. Endoscopic bilateral congenital choanal atresia repair of 112 cases, evolving concept and technical experience. Int J Pediatr Otorhinolaryngol. 2016;85:40-5.

260. Hong CJ, Monteiro E, Badhiwala J, Lee J, de Almeida JR, Vescan $A$, et al. Open versus endoscopic septoplasty techniques: A systematic review and meta-analysis. Am J Rhinol Allergy. 2016:30:436-42.

261. Wilson MA, Mobley SR. Extracorporeal Septoplasty. Am Med Assoc. 2013;13:85-90. 
262. Dosen LK, Haye R. Surgical closure of nasal septal perforation. Early and long term observations. Rhinology. 2011;49:486-91.

263. Cassano M. Endoscopic Repair of Nasal Septal Perforation with "Slide and Patch" Technique. Otolaryngol Head Neck Surg. 2014;151:176-8.

264. Hanci D, Altun H. Repair of nasal septal perforation using middle turbinate flap (monopedicled superiory based bone included conchal flap): a new unilateral middle turbinate mucosal flap technique. Eur Arch Oto-Rhino-Laryngology. 2015;272:1707-12.

265. Kim S-W, Rhee C-S. Nasal septal perforation repair. Curr Opin Otolaryngol Head Neck Surg. 2012;20:58-65.

266. Castelnuovo P, Ferreli F, Khodaei I, Palma P. Anterior Ethmoidal Artery Septal Flap for the Management of Septal Perforation. Arch Facial Plast Surg. 2011;13:411-4.

267. Outcomes M, Evidence LOF. Long-term Results of Combined Rhinoplasty and Septal Perforation Repair. 2016;18:1-6.

268. Park JH, Kim DW, Jin HR. Nasal septal perforation repair using intranasal rotation and advancement flaps. Am J Rhinol Allergy. 2013;27:42-7.

269. Williams R, Lee MK, Most SP. Large Septal Perforation Repair with Pericranial Flap and Intraoperative Fluorescence Angiography. 2016;1:181-4.
270. Lund VJ, Stammberger $H$, Nicolai $P$, Castelnuovo $P$, Beal $T$, Beham $A$, et al. European position paper on endoscopic management of tumours of the nose, paranasal sinuses and skull base. Rhinol Suppl. 2010;1-143.

271. Lund VJ, Clarke PM, Swift AC, McGarry GW, Kerawala C, Carnell D. Nose and paranasal sinus tumours: United Kingdom National Multidisciplinary Guidelines. J Laryngol Otol. 2016;130:\$111-8.

- Manuscript received January 8, 2018; accepted for publication January 18, 2018.

\section{- Antonio Valero Santiago}

Servei d'Al·lèrgia, Hospital Clínic

C/ Villarroel, 170

08036 Barcelona, Spain

E-mail: valero@clinic.cat 